Tail Risk and the Cross-Section of Mutual Fund Expected Returns

\author{
Nikolaos Karagiannis, and Konstantinos Tolikas*
}

\begin{abstract}
* Karagiannis, nikolaos.karagiannis@kuleuven.be, Department of Accounting, Finance and Insurance, Faculty of Economics and Business, KU Leuven; Tolikas (corresponding author), k.tolikas@aston.ac.uk, Aston Business School, Aston University. We are grateful to the anonymous referee and Jennifer Conrad (the Editor) whose thoughtful and constructive comments helped to substantially improve our paper. We also thank Hans Degryse, Chris Florackis, and Alexandros Kostakis for helpful comments.
\end{abstract}




\title{
Tail Risk and the Cross-Section of Mutual Fund Expected Returns
}

\begin{abstract}
We test for the presence of a tail risk premium in the cross-section of mutual fund returns and find that the top tail risk quintile of funds outperforms the bottom by $4.4 \%$ per annum. This premium is not simply a reward for market risk, nor do commonly used risk factors offer an adequate explanation. Our findings hold across double-sorted portfolios formed on tail risk and a number of fund characteristics. We also find that funds susceptible to tail risk tend to be small, young, have high management fees, and have managers who do not risk their own capital.
\end{abstract}




\section{Introduction}

A growing body of the asset pricing literature focuses on the relation between tail risk and the cross-section of the expected asset returns. Indeed, it has long been recognized that risk averse investors care differently about the tail asset returns as opposed to asset returns that fall in the central part of the empirical distribution of returns, mainly because tail events can lead to a significant reduction in a portfolio's value (see, e.g., Ang, Chen, and Xing (2006), Roy (1952)). ${ }^{1}$ These tail events represent states of high marginal utility that investors are thus willing to pay large sums to insure against, while demanding a high expected return to hold assets that might suffer considerably from a tail event. Thus, tail risk might have a large impact on asset prices even if tail events occur infrequently. ${ }^{2}$ Indeed, recent asset pricing studies demonstrate that a tail risk premium exists in the cross-section of asset returns, which is not simply a reward for commonly used risk factors (see, e.g., Agarwal, Ruenzi, and Weigert (2017), Ang et al. (2006), Bali, Demirtas, and Levy (2009), Bollerslev and Todorov (2011), Chang, Christoffersen, and Jacobs (2013), Farago and Tédongap (2017), Kelly and Jiang (2014), Lettau, Maggiori, and Weber (2014), Weigert (2016)).

Motivated by this part of the asset pricing literature, we examine the presence of a tail risk premium in the cross-section of actively managed US equity mutual fund returns. This part of the fund industry is an interesting field to examine the asset pricing effects of tail risk because active equity funds are subject to sources of tail risk not inherent in the individual stocks in their

\footnotetext{
${ }^{1}$ Notable examples include the 1987 stock market crash, the 1997 Asia Crisis, the 2000 dot-com bubble, the 2008 credit crunch, and the 2015 Chinese stock market crash.

${ }^{2}$ Welch (2016) uses the prices of far-below-the-money puts to show that tail risk can account for up to $2 \%$ of the equity premium.
} 
portfolios. Indeed, it is well documented that the majority of equity mutual funds follow momentum trading strategies which despite their remarkable performance have a dark side because they also come with occasional large crashes (see, e.g., Badrinath and Wahal (2002), Barroso and Santa-Clara (2015), Daniel, Jagannathan, and Kim (2017), Daniel and Moskowitz (2016), De Long, Shleifer, Summers, and Waldmann (1990), Grinblatt, Titman, and Wermers (1995)). ${ }^{3}$ Further, the tendency of mutual funds to herd can also destabilize prices and lead to significant crash risk (see, e.g., Brown, Wei, and Wermers (2014), Dass, Massa, and Patgiri (2008), Lakonishok, Shleifer, and Vishny (1992), Nofsinger and Sias (1999), Sias (2004), Wermers (1999)). A number of studies also find that mutual funds that experience extreme flows might be forced to engage in fire sales of stocks that lead to large swings in prices (see, e.g., Adam and Klipper (2017), Coval and Stafford (2007), Edelen (1999), Rakowski (2010)). Our motivation is further strengthened by the increasing importance of the mutual fund industry to the US economy. Indeed, the mutual fund market is one of the largest and fastest growing financial markets. ${ }^{4}$ The total net assets of mutual funds in the US amounted to $\$ 15.7$ trillion at the end of 2015, with equity funds being the fastest growing part of this industry representing

\footnotetext{
${ }^{3}$ Daniel and Moskowitz (2016) show that the large gains from a US equity momentum strategy come at the expense of a very high excess kurtosis of 18.24 combined with a pronounced left skewness of -2.47 . These two attributes of the momentum strategy indicate a very fat left tail and significant crash risk. Further, Barroso and Santa-Clara (2015) report that in 1932, the US equity Winners-Losers strategy suffered a negative return of $-91.59 \%$ in just two months, while in 2009, the momentum strategy experienced a crash of $-73.42 \%$ in just three months. Barroso and Santa-Clara conclude that the large returns of momentum strategies do not really compensate reasonably risk averse investors for crashes that might wipe out decades of fund returns.

${ }^{4}$ The evidence regarding the performance of actively managed mutual funds relative to a set of benchmarks is rather inconclusive and therefore cannot by itself explain satisfactory the growth in actively managed funds (see, e.g., Fama and French (2010), Carhart (1997), Grinblatt and Titman (1992), Gruber (1996), Wermers (2000)). Gruber (1996) suggests that the presence of 'disadvantaged' investors who are ignorant of the underperformance of actively managed mutual funds or behave irrationally might explain the growth in active funds; this is also echoed in Berk and van Binsbergen (2015) and Del Guercio and Reuter (2014). Pastor and Stambaugh (2012) also propose a resolution to this puzzle based on the idea of decreasing returns to scale.
} 
$52 \%$ of all mutual fund assets. Households also increasingly rely on mutual funds to meet their long-term financial objectives of total wealth. For example, households' financial assets held in mutual funds grew from $2 \%$ in 1980 to $22 \%$ by the end of 2015 , with households currently holding $89 \%$ of all mutual fund assets. Further, the percentage of these assets in defined contribution retirement plans grew from 26\% in 1995 to 54\% in 2015 (ICI, 2016). Mutual funds have also become increasingly important in setting stock prices. For instance, mutual fund equity holdings have increased relative to the NYSE market capitalization from $15 \%$ in 1980 to $44 \%$ at the end of 2015. As such, examining the impact of tail risk in the cross-section of returns of equity mutual funds as well as its relation to fund characteristics is important.

We adopt a measure of aggregate tail risk developed by Kelly (2014) that applies the Hill estimator to infer the power law probabilities of tail events (Hill, 1975). This measure of timevarying tail risk is derived directly from the cross-section of asset returns using a panel estimation approach. This approach has a number of advantages. First, it overcomes the common problem of the tail risk analysis in finance that relates to the limited number of returns available. ${ }^{5}$ Second, it can investigate tail risk without resorting to the approach based on rare economic disasters. ${ }^{6}$ Third, its novel construction accounts for the time-varying nature of tail risk. Kelly and Jiang (2014) identify common fluctuations in tail risk among individual stocks by using firm-level monthly price crashes. They find that time-varying tail risk has significant predictive

\footnotetext{
${ }^{5}$ Classic Extreme Value Theory defines the tail returns as either the maximum (or minimum) returns over nonoverlapping time periods of equal length (block maxima approach), or as excesses over a high enough threshold (Peaks-over-Threshold approach). Both approaches require long series of returns for sound tail risk estimates.

${ }^{6}$ Our study also relates to the literature that examines the potential of rare economic disasters to explain the equity premium (see, e.g., Barro (2006), Berkman, Jacobsen, and Lee (2011), Gabaix (2012), Tsai and Wachter (2015), Wachter (2013)). Despite the potential of this strand of the literature, the limitation related to the relatively low number of rare economic disasters renders the construction of a dynamic tail risk measure a difficult, if not impossible, task.
} 
power for aggregate stock market returns and that cross-sectionally, stocks with high loadings on tail risk are rewarded with an annual three-factor alpha that is about $4.0 \%$ per annum higher than the alpha of stocks with low tail risk loadings.

Our study addresses the following questions: (i) Does tail risk help to explain the crosssectional variation in fund returns? and (ii) Do certain fund characteristics help to explain their susceptibility to tail risk? We use daily mutual fund returns over the period from January 01, 1985 , to September 30,2015, to estimate the aggregate tail risk in the mutual fund market. We then estimate the tail risk sensitivity of each fund to the aggregate tail risk, sort the funds according to their tail risk loadings, and construct equal- and value-weighted tail risk quintile portfolios. We account for commonly used risk factors like market risk, size, book-to-market, momentum, and liquidity (Fama and French (1993), Carhart (1997), Pastor and Stambaugh (2003)), and we then assess whether a tail risk premium exists in the cross-section of fund returns. Overall, the results show that tail risk has significant explanatory power for the variation in the cross-sectional mutual fund expected returns. For example, equal-weighted fund portfolios that belong in the highest tail risk quintile generate an additional annualized return of $4.4 \%$ compared to portfolios that belong in the lowest tail risk quintile. This additional tail risk reward is statistically significant with a $t$-statistic of 2.38, using Newey and West (1987) corrected standard errors. To ensure that tail risk, rather than mutual fund characteristics, is driving the differences in the cross-sectional returns that we find, we perform a series of bivariate sorts and re-examine the relation between the cross-sectional fund returns and their exposure to tail risk. The results are robust to sorts on Morningstar's equity style classifications, benchmark alpha, fund size, expense ratio, turnover ratio, tracking error, management fees, and managerial ownership. Our findings support the hypothesis that funds with high loadings on tail risk receive 
a lower valuation from risk averse investors and thus higher expected returns compared to funds with low loadings on tail risk. Further, our findings indicate that the superior performance of some of the fund managers might be due to their portfolios' exposure to tail risk rather than their stock-picking ability. We also examine the relation between aggregate tail risk and a number of mutual fund characteristics. Overall, our results indicate that funds susceptible to tail risk tend to be small, young, have high management fees, and have managers who do not risk their own capital. These characteristics explain as much as $30 \%$ of the cross-sectional variation in the tail risk loadings.

This study makes several contributions. First, we contribute to the growing literature on the impact of tail risk on asset prices by providing evidence related to mutual funds. Second, we provide evidence for the presence of a tail risk premium in the cross-section of the equity mutual fund returns. Third, we show that the tail risk premium is statistically and economically significant, even after controlling for commonly used risk factors, and that our results are robust to a number of important fund characteristics. Fourth, we provide evidence that certain characteristics are related to mutual funds' susceptibility to tail risk.

The rest of this paper is organized as follows. Section II describes the dataset of the US actively managed equity mutual funds that we use in this paper. Section III presents the time varying aggregate tail risk measure and the methodological framework we adopt. In Section V we test for the presence of a tail risk premium in the cross-section of fund returns, and in Section VI we investigate the relation between tail risk susceptibility and fund characteristics. Section VII concludes the paper. 


\section{Data and Sample selection}

Our sample consists of all US equity diversified open-end mutual funds and is provided by Morningstar and includes all defunct funds (i.e., merged, and liquidated). The sample comprises all actively managed funds from January 01,1985 , to September 30, 2015. The sample starts in January 1985 because the estimation of the Hill power law is based on the lowest $5 \%$ of the daily returns pooled over a period of one month for all funds in the sample. ${ }^{7}$ As of January 1985 , there were 145 funds in our sample. This sampling results in a total of 3,190 daily returns and provides 160 daily returns for the calculation of the Hill estimator for January 1985. This number is high enough to allow for a reliable estimation of the aggregate tail risk. The number of funds in the sample for each month is always higher than the number in January 1985. We exclude sector funds, international funds, and balanced funds because they are driven by different risk factors than those of the domestic equity funds. We also drop those funds for which there are less than 60 consecutive monthly returns available because this is the number of returns we use in the predictive regressions we run in Section V. Further, for the funds with multiple share classes we use only the oldest share class as the representative one. The final sample comprises 1,750 actively managed mutual funds and 27,104 fund years. The number of funds over this time period varies considerably, ranging from a minimum of 145 in January 1985 to a maximum of 1,740 in October 2010. We also divide our sample according to the Morningstar's equity style classification as Large-cap Value (270), Large-cap Blend (310), Large-cap Growth (383), Mid-

\footnotetext{
${ }^{7} \mathrm{We}$ have also used the lowest $2 \%$ and $3 \%$ of fund daily returns which result in a minimum of 64 and 96 daily returns, respectively, available for the estimation of the Hill power law. The results are qualitatively similar and lead to the same conclusions. In the interest of brevity, we do not report these results in this paper.
} 
cap Value (85), Mid-cap Blend (85), Mid-cap Growth (166), Small-cap Value (90), Small-cap

Blend (162), and Small-cap Growth (199). ${ }^{8}$

***Insert Table 1 around here***

Table 1 presents a summary description of the funds in our sample. The average year has 962 funds, with an average minimum of 158 and an average maximum of 1,731. The average annual assets under management (AUM) is just over $\$ 1.2$ billion, the average annual gross expense ratio is $1.16 \%$, and the average turnover ratio is $80.12 \%$. Further, the table contains the same characteristics divided into Morningstar's nine equity styles. Large-cap funds represent $55 \%$ (963) of the sample, followed by $25.8 \%$ (451) for Small-cap funds, and $19.2 \%$ (336) for Mid-cap funds. The average AUM for the Large-cap funds is the largest (\$1.6 billion), followed by the Mid-cap funds ( $\$ 0.7$ billion) and the Small-cap funds ( $\$ 0.4$ billion). The average annual gross expense ratio is larger for the Small-cap funds (1.46\%), followed by the Mid-cap funds $(1.38 \%)$ and the Large-cap funds (1.23\%). Further, Mid-cap funds have the highest average annual turnover ratio at $98.50 \%$ indicating that they are turning over nearly all of their holdings every year, followed by the Small-cap funds (74\%) and the Large-cap funds (72\%). Figure 1 shows the growth of the average size and the average number of the funds for the sample period.

\footnotetext{
${ }^{8}$ Morningstar's equity style classification is a three-by-three grid that categorises funds by market capitalization and growth and value factors. The nine equity style classifications are: Large-cap Value: funds that invest mainly in big US firms that are less expensive or grow more slowly than other large-cap stocks; Large-cap Blend: funds that own portfolios that are fairly representative of the overall US stock market in size, growth, and price; Large-cap Growth: funds that invest mainly in big US firms that are likely to grow faster than other large-cap stocks; Mid-cap Value: funds that invest mainly in medium-size firms, including portfolios that own a mix of small-, mid-, and large-cap stocks; Mid-cap Blend: funds that invest in US firms of various sizes and styles; Mid-cap Growth: funds that invest mainly in US stocks of all sizes; Small-cap Value: funds that invest mainly in small US firms with valuations and growth rates lower than other small-cap peers; Small-cap Blend: funds that invest mainly in US firms in the smaller end of the market capitalization range; and Small-cap Growth: funds that invest mainly in faster growing firms whose shares are at the lower end of the market capitalization range.
} 
With a small number of exemptions both series tend to increase over time with the average fund size reaching its peak in 2015 and the average number of funds peaking in 2011.

\footnotetext{
*** Insert Figure 1 around here ${ }^{* * *}$
}

Table 2 contains the summary statistics for the average monthly gross returns of the funds in our sample. We report the results for an equal-weighted portfolio of all funds as well as equalweighted portfolios based on the Morningstar's nine equity styles. In general, the average monthly return is lower for the Large-cap funds and higher for the Mid- and Small-cap funds. However, the average standard deviation of returns for Mid- and Small-cap funds is higher. In addition, the minimum (maximum) returns of Mid- and Small-cap funds are smaller (larger) than the minimum (maximum) returns of Large-cap funds. The average values of skewness and kurtosis for most of the funds' returns indicate that the returns are not normally distributed; this is confirmed by the Jarque-Bera normality test for all fund portfolios.

$$
\text { ***Insert Table } 2 \text { around here*** }
$$

\section{Definition and Estimation of Aggregate Tail Risk in Mutual funds}

Constructing a measure of time-varying tail risk in a univariate time series setting is challenging because tail events are rare by their nature. Kelly and Jiang (2014) adopt a panel estimation approach based on the cross-section of daily asset returns. In this approach, a fat tailed probability distribution is characterized by a power law decay as opposed to the exponential decay of the normal distribution. The lower tail returns behave according to the following probability condition: 


$$
\operatorname{Prob}\left(R_{i, t+1}<r \mid R_{i, t+1}<u_{t}, \text { and } F_{t}\right)=\left(\frac{r}{u_{t}}\right)^{-\alpha_{i} / \lambda_{t}}
$$

where $R_{i, t+1}$ is the return of mutual fund $i$ at time $t+1$ that is less than a threshold $u_{t, \text {. The threshold }}$ defines the lower tail of the probability distribution of the cross-sectional returns (i.e., $r<u_{t}<0$ ), and $F_{t}$ is the information set available at time $t$. Typically, $u_{t}$ is one of the lower quantiles of the cross-sectional distribution of returns defined by $\hat{u}_{t}(q)=i n f_{i}\left\{R_{(i), t} \in R_{t}: \frac{q}{100} \leq \frac{(i)}{n}\right\}$, where $(i)$ is the $i^{\text {th }}$ order statistic of the $(n \times 1)$ vector $R_{t}$. In this study, we set $u_{t}$ equal to the $5^{\text {th }}$ percentile (i.e., $q=5$ ) of the cross-sectional distribution of the funds' returns at time $t$. We base this choice on the theoretical rule of Gabaix, Gopikrishnan, and Plerou (2006), who suggest fixing the probability of exceeding $u$ at 5\%, and the empirical investigation by Kelly and Jiang (2014) who report that ranging the fixed percentile from $1 \%$ to $5 \%$ leads to similar empirical results. The estimation of $u_{t}$ on a period-by-period basis means that its actual value varies as the volatility of the cross-sectional distribution of returns varies period-by-period; thus, high cross-sectional volatility tends to lead to high absolute threshold values of $u_{t}$ and vice versa. This time-varying threshold mitigates the effects of volatility changes and facilitates the estimation of the unaffected tail risk if, for example, the volatility increases substantially but the shape of the lower tail remains the same. Thus, our choice of tail risk measure accounts for the common timevarying volatility of the mutual funds' returns.

The shape of the tail of the cross-sectional distribution of the returns is determined by the tail exponent, $\alpha_{i} / \lambda_{t}$. The higher the tail risk measure $\lambda_{t}$, the fatter the lower tail of returns, and therefore the higher the probability of a tail return occurring, and vice versa. We use a panel estimation approach to construct the time-varying monthly common tail risk over the sample 
period. This approach is based on the commonality of tail risk across the individual mutual funds. Different mutual funds are allowed to have different levels of tail risk, which are determined by the parameter $\alpha_{i}$, while they can share similar tail risk dynamics, that are determined by the parameter $\lambda_{t}$. Individual funds might have different idiosyncratic tail risks, but their common tail risk dynamics are determined by a single process across all funds. Assuming a sufficiently high number of funds this approach can adequately model the aggregate tail risk in equity mutual funds.

We estimate the aggregate time-varying tail risk in the mutual fund market by using the cross-section of daily returns of the equity mutual funds in our sample, rather than the crosssection of stock returns. ${ }^{9}$ We follow this approach since dynamic trading strategies that actively managed equity funds tend to follow can generate sources of tail risk which differ from those in the individual stocks in their portfolios (see, e.g., Adam and Klipper (2017), Coval and Stafford (2007), Daniel and Moskowitz (2016), Dass et al. (2008), De Long et al. (1990), Wermers (1999)). It is also important to note that the theoretical foundations that Kelly and Jiang (2014) provide for using stock returns in the calculation of aggregate tail risk, also hold in the case of domestic equity mutual funds. First, because power law distributions are stable under aggregation, the market-level tail risks of funds are mathematically linked to common dynamics in fund-level tail risks. Thus, in a sufficiently large cross-section, fund-level tail distributions are informative about the likelihood of market-wide tail events for mutual funds. Second, the literature on the real business cycle suggests that changes in uncertainty (i.e., tail risk in our context) affect the marginal utility of investors and consequently asset prices (Bloom (2009),

\footnotetext{
${ }^{9}$ We have also reproduced the results in Tables 3, 4, 5, and 6, using the aggregate tail risk estimated from the crosssection of the daily returns of the NYSE, AMEX, and NASDAQ stocks with share codes 10 and 11 obtained from CRSP. In general, the empirical results lead to the similar conclusions.
} 
Gourio (2012)). It follows that for pricing effects to exist via the channel of uncertain tail shocks, common tail risk in the cross-section of stock returns ultimately must be associated with aggregate real economic outcomes. The same argument also holds in the case of equity funds in our sample because their portfolios are made up mostly of domestic equity. ${ }^{10}$

In order to estimate the common tail risk $\lambda_{t}$ on a month-by-month basis, we pool the daily cross-sectional returns of all funds for each month, which increases our sample size and therefore reduces the estimation error. ${ }^{11}$ This approach accommodates size changes in the cross-section over time. We then calculate the Hill power law estimator:

$$
\lambda_{t}^{H i l l}=\frac{1}{K_{t}} \sum_{k=1}^{K_{t}}\left[\ln \left(R_{k, t}\right)-\ln \left(u_{t}\right)\right]
$$

where $R_{k, t}$ is the $k^{\text {th }}$ daily fund return that is lower than the threshold $u_{t}$ in month $t$, and $K_{t}$ is the total number of the cross-sectional returns below the threshold $u_{t}$ within month $t$. We use the lower $5 \%$ of the daily returns of all funds in the sample to calculate estimates of aggregate tail risk $\lambda_{t}$ on a monthly basis from January 1985 to September 2015. Figure 2 plots the $\lambda_{t}$ together with the three-year subsequent return of an equal-weighted portfolio of all funds in the sample. A visual inspection indicates a relation between these time series that the coefficient of correlation confirms with a value of $42 \%$, which indicates that tail risk might be one of the long-term drivers of mutual fund returns. We also detect a high degree of commonality in the time-varying common tail risks across fund portfolios formed according to Morningstar's equity style classification. Indeed, the correlation coefficients across the tail risks of different portfolios of

\footnotetext{
${ }^{10}$ In our sample of 1,750 active funds, the average fund portfolio is made up of $89.98 \%$ US equity (net), $4.88 \%$ nonUS equity (net), $4.05 \%$ cash (net), $0.24 \%$ US bonds (net), $0.06 \%$ non-US bonds (net), and $0.75 \%$ in other assets (net).

${ }^{11}$ This is based on the property of stability under the aggregation of the power law distributions; see Gabaix (2009) for the properties of power law distributions.
} 
funds formed on their equity style range from $42 \%$ to $87 \%$, which supports the existence of common tail risk dynamics.

***Insert Figure 2 around here***

\section{Tail Risk and the Cross-section of Mutual Fund Returns}

Rational and risk averse investors are concerned about the likelihood of a significant reduction in their portfolios' values due to an unforeseen lower tail event. We argue that rational investors require a higher expected return to hold funds with higher exposure to tail risk. Similarly, investors settle for a lower expected return when they invest in funds with lower tail risk exposure. If this argument is correct, then tail risk should be helpful in explaining the variation in the cross-section of mutual fund expected returns. To examine this argument, we start by estimating the sensitivity of the monthly returns of all mutual funds in our sample to the aggregate tail risk $\lambda_{t}$. In particular, for each fund, we run the following predictive regression:

$$
r_{i, t+1}=\delta_{i}+\beta_{i} \lambda_{t}+\vartheta_{i, t+1}
$$

where $r_{i, t+1}$ is the realized monthly return of fund $i$ at time $t+1, \delta_{i}$ is the intercept term for fund $i, \beta_{i}$ is the sensitivity of the monthly return of fund $i$ to the aggregate tail risk $\lambda_{t}$, and $\vartheta_{i, t+1}$ is an error term. ${ }^{12}$ This specification allows us to test whether funds with high $\beta s$ are not good hedges against tail events. This is because when tail risk rises, these funds are likely to suffer considerably from a tail event. Thus, investors demand a significant price discount to hold funds with high $\beta s$ which in equilibrium increases their expected returns. Analogously, funds with low

\footnotetext{
${ }^{12}$ Similar to Kelly and Jiang (2014), we use predictive regressions on the level of $\lambda$ instead of contemporaneous regressions on $\lambda$ 's shocks (e.g., $\mathrm{AR}(1)$ innovations) to reduce the influence of $\lambda$ 's estimation error on the estimation of the tail risk loadings.
} 
or negative $\beta s$ serve as effective hedges; when tail risk rises, the expected returns of these funds decrease in equilibrium because investors are willing to pay a premium to insure states of high tail risk. The regressions are run at monthly frequency using a monthly rolling window with length equal to the most recent 60 monthly returns (i.e., starting with the monthly returns from January 1985 to December 1989). Hence, for each month $t$, from January 1990 to September 2015 , we estimate a tail risk loading, $\beta_{i, t}$, for each fund $i$. We use the estimated tail risk loading for each fund in December and June of each year to sort all funds, and we construct equal- and value-weighted quintile portfolios that we rebalance every 12 months (i.e., every December) and 6 months (i.e., every June and December) based on the funds' new tail risk loadings. We then track the average out-of-sample monthly returns of the constructed quintile portfolios. Table 3 contains the results.

\section{***Insert Table 3 around here***}

The results show a strict monotonic pattern in the average monthly returns for both the equal- and value-weighted portfolios. ${ }^{13}$ Panel A shows that for the equal-weighted portfolios with 12-month rebalancing, funds in the lowest tail risk quintile have an average monthly return of $0.82 \%$, while funds in the highest tail risk quintile have an average monthly return of $1.19 \%$. We also form the High-Low portfolio that represents the effect of a zero net investment strategy of buying funds with high tail risk loadings and shorting funds with low tail risk loadings. If such a strategy is possible, then the returns on the funds with high tail risk loadings should mostly drive the return of the High-Low portfolio. The average monthly return of the High-Low

\footnotetext{
${ }^{13}$ For robustness, we also consider 3-month and 1-month rebalancing frequencies. The results are quantitatively similar.
} 
portfolio is $0.37 \%$, which implies an average annual return of $4.44 \%$ that is statistically significant with a Newey-West $t$-statistic of $2.376 .{ }^{14}$ The results are similar for the portfolios with 6-month rebalancing, as well as for the value-weighted portfolios in Panel B. Overall, the results show that funds with high tail risk loadings tend to earn higher monthly returns than the funds with lower tail risk loadings.

We also assess whether the tail risk premium persists after controlling for commonly used risk factors in the time series of portfolio returns. Specifically, we control for risk including the market, the size and book-to-market (Fama and French, 1993), the momentum (Carhart, 1997), and the liquidity (Pastor and Stambaugh, 2003) risk factors. In Table 3, we report the alphas obtained by applying these models to the monthly returns of the equal- and valueweighted tail risk quintile portfolios. ${ }^{15}$ For both the equal- and value-weighted portfolios, we observe a strict monotonic increase in the monthly alphas for all models. The alphas for the High-Low equal-weighted portfolios with 12-month rebalancing are all large and statistically significant at the $1 \%$ level. The fund portfolios in the highest quintile earn a four-factor alpha that is $3.48 \%$ higher in annual terms than the fund portfolios in the lowest tail risk quintile. This number is also statistically significant with a Newey-West $t$-statistic of 2.503 . For the 6-month rebalanced equal-weighted portfolios, all of the alphas except for the Fama and French model are statistically significant at the $10 \%$ level. Further, on a value-weighted basis, the alphas for both the 12- and 6-month rebalanced quintile portfolios are all statistically significant at commonly used significance levels. These differences in the estimated alphas clearly indicate the presence

\footnotetext{
${ }^{14}$ The optimal number of lags for the Newey-West $t$-statistic is derived following Newey and West (1994).

${ }^{15}$ Monthly data for the size, book-to-market, and momentum factors are obtained from Kenneth French's website. Monthly data for the liquidity factor are obtained from Lubos Pastor's website.
} 
of a tail risk premium which is not simply a reward for market risk, size, book-to-market, momentum, or liquidity. These results might also indicate that the monthly alpha in excess of the reward for standard pricing factors does not necessarily reflect managerial skill but merely the willingness of fund managers to hold portfolios with high tail risk loadings. If this is the case, accounting for tail risk susceptibility in evaluating mutual fund managers' performance is crucial.

In Table 4, we independently double-sort the funds in our sample on their tail risk betas and Morningstar's equity style classifications and examine the average out-of-sample monthly returns for both the equal- and value-weighted quintile portfolios with 12-month rebalancing. For most portfolios, we observe the same increasing monotonicity as for the portfolios sorted only on their tail risk loadings. The average monthly return for the High-Low equal-weighted portfolio is higher for the Large-cap portfolios $(0.17 \%)$, followed by the Small-cap portfolios $(0.13 \%)$, and the Mid-cap portfolios $(0.11 \%)$. Further, the average monthly return for the High-Low Large-cap Value portfolio is $0.33 \%$, which indicates an average annual return of $3.96 \%$ that is considerably lower than its value-weighted counterpart of 5.88\%. Further, Figures 3 and 4 show the monthly alphas from applying the CAPM, Fama and French three-factor model, Carhart four-factor model, and the Pastor and Stambaugh five-factor model to the monthly returns of the equal- and value-weighted High-Low portfolios, respectively, formed according to Morningstar's equity style classifications. We observe that the alphas for the High-Low portfolios remain large and 
statistically significant in almost all cases. Overall, the empirical results indicate a substantial premium for the funds with high tail risk loadings. ${ }^{16}$

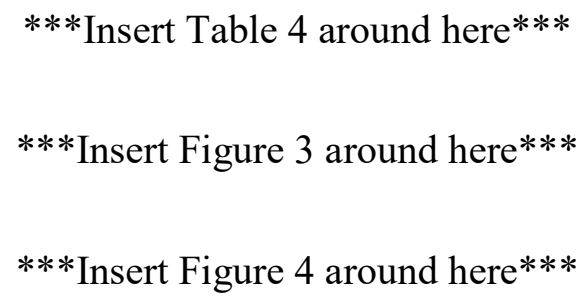

We also examine whether our results are robust to several important mutual fund characteristics by independently double-sorting funds on tail risk loadings and each of these characteristics. Our choice to examine the effects of fund characteristics on the return offered by funds of different tail risk susceptibility is motivated by prior literature which has indicated the significance of these characteristics to the performance of mutual funds (see, e.g., Chen, Hong, Huang, and Kubik (2004), Grinblatt and Titman (1989), Roll (1992), Khorana, Servaes, and Wedge (2007), Wermers (2000)). These characteristics comprise the benchmark alpha (BNCH_ALPHA), fund size (SIZE), expense ratio (EXP_RATIO), turnover ratio (TURN_OVER), tracking error (TR_ERROR), management fee (MNG_FEE), and managerial ownership (MNG_OWN). The benchmark alpha measures a fund's performance after adjusting for the fund's systematic risk as measured by its beta with respect to its primary prospectus benchmark. The fund size is the total amount of money managed as a standalone portfolio across share classes and subaccounts. The expense ratio is the percentage of the fund's average total net

\footnotetext{
${ }^{16}$ The value premium puzzle is also present in the results. In particular, the High-Low portfolios for the valueoriented funds (i.e., Large-cap Value, Mid-cap Value, and Small-cap Value) have higher average monthly returns (i.e., $0.16 \%$ monthly or $1.92 \%$ annually) than the growth-oriented funds (i.e., $0.12 \%$ monthly or $1.44 \%$ annually). This finding might seem like a puzzle because the value-oriented funds have substantially lower volatility than the growth-oriented funds (see Table 2). However, Tsai and Wachter (2015) provide an explanation for this puzzle that is based on rare events. Specifically, they show that although value stocks are not riskier than growth stocks on the basis of conventional risk measures, they tend to have higher tail risk related premiums than growth stocks.
} 
assets deducted every year for gross expenses that include distribution fees, management fees, administrative fees, and operating costs, but exclude transaction costs and sales charges. The turnover ratio measures the value of the trading activity of the fund as a percentage of the average total net assets of the fund. ${ }^{17}$ The tracking error measures how well a fund tracks its benchmark portfolio and is measured as the volatility of the difference between a fund's excess return relative to its primary prospectus benchmark. The management fee measures the percentage of the total net assets of the fund charged every year by the manager to cover the cost of running the fund. The managerial ownership is a measure of how much the managers own in the fund (Morningstar Direct, 2017). Sorting on tail risk loadings, and benchmark alpha, fund size, turnover ratio, tracking error, and managerial ownership takes place monthly, and for the expense ratio and management fee the sorting is annual. Since 2005 the US Securities and Exchange Commission (SEC) has required that managers of US mutual funds disclose how much of their personal capital is invested in the funds they manage, using the following ranges: $\$ 0$, from $\$ 1$ to $\$ 10,000$, from $\$ 10,001$ to $\$ 50,000$, from $\$ 50,001$ to $\$ 100,000$, from $\$ 100,001$ to $\$ 500,000$, from $\$ 500,001$ to $\$ 1,000,000$, and over $\$ 1,000,000$. Although the disclosure of managerial ownership is not exact, it still leaves us with sufficient cross-sectional variation to study the robustness of our findings to different managerial ownership levels. We further follow Khorana et al. (2007) to convert the disclosed managerial ownership into the percentage of managerial ownership, which is most often used in the literature (see, e.g., Jensen and Meckling (1976)). In particular, we assume that each manager's ownership is at the midpoint of the disclosed range. For example, if a manager discloses ownership in the $\$ 50,001$ to $\$ 100,000$

\footnotetext{
${ }^{17}$ US SEC measures the fund's portfolio trading activity by taking the lesser of purchases or sales, excluding all securities with maturities of less than one year, and dividing by the average monthly net assets.
} 
range, we assume that he owns $\$ 75,000$ worth of the fund shares. For managerial ownership above $\$ 1,000,000$ we assume the manager's ownership is at the bottom of the range. Further, when a fund has multiple managers we add up the ownership stakes of each to determine the aggregate managerial ownership in a fund. We then convert the dollar ownership into percentage ownership by dividing the dollar ownership by the fund's size. All data are collected from Morningstar with the exception of the management fee which is collected from the CRSP Mutual Fund database.

We construct equal- and value-weighted double-sorted portfolios, which we rebalance every 12 months (i.e., every December), and we report their average out-of-sample monthly returns in Table 5. The results indicate that the average monthly returns of the funds in each of the tail risk quintiles increase as the benchmark alpha increases, which supports the argument of performance persistence in mutual funds. Further, the average monthly returns of the funds in each of the benchmark alpha quintiles increase as the tail risk loadings increase. For example, the average monthly return of the funds in benchmark alpha quintile 1 increases from $0.71 \%$ in tail quintile 1 to $1.05 \%$ in tail quintile 5 . This difference is equivalent to an annual difference of $4.08 \%$, which is economically significant and statistically significant at the $10 \%$ level. These findings indicate that the superior performance of some fund managers might be also attributed to their high exposure to tail risk rather than only to their stock-picking ability. Similar inferences can be made based on the findings for fund portfolios that are double-sorted on tail risk betas and a number of fund characteristics. The results for the value-weighted portfolios also confirm these findings.

We also examine monthly alphas estimated by applying the CAPM, the Fama and French, the Carhart, and the Pastor and Stambaugh models on the monthly returns of the equal- 
and value-weighted quintile portfolios formed by independent sorts of the funds on tail risk betas and fund characteristics. Table 6 reports the alphas from the Carhart model for all double-sorted quintile portfolios. ${ }^{18}$ For all characteristics, the results show an almost strictly increasing monotonic pattern in the monthly alphas of the tail risk quintile portfolios for both the equal- and value-weighted portfolios.

Overall, our results strongly indicate that tail risk is an important determinant of the cross-sectional variation in equity mutual fund returns. These results indicate the presence of a tail risk premium which is not simply a reward for market risk, size, book-to-market, momentum, or liquidity. Further, our results are robust across double-sorted portfolios formed on tail risk betas and a number of important fund characteristics.

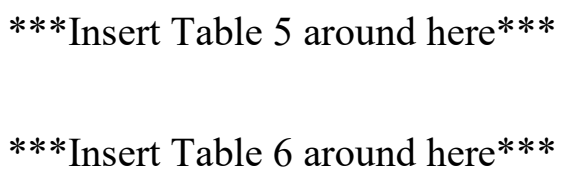

\section{The Relation between Tail Risk and Mutual Fund Characteristics}

In this section, we investigate the relation between the funds' sensitivity to aggregate tail risk and a number of mutual fund characteristics. We divide these characteristics into two groups. The first group comprises the fund's size (in \$billions), age (AGE) (in years), and corporate governance score (CGS) (on a scale from 0 (worst) to 100 (best)). The second group comprises the management fee (in \%), manager tenure (MNG_TEN) (in years), and managerial ownership (in \%). Descriptions of fund size, management fee, and managerial ownership are provided in Section V. The fund's age is the number of years since its inception. The fund's corporate

\footnotetext{
${ }^{18}$ The results are qualitatively similar for all other models leading to the same conclusions. In the interest of brevity, they are not reported in this paper.
} 
governance score is the asset-weighted average of the Sustainalytics governance scores for the covered holdings in its portfolio. ${ }^{19}$ These governance scores are based on detailed analysis of board integrity and quality, board structure, ownership and shareholder rights, remuneration, financial reporting, and stakeholder governance. The manager's tenure is the number of years that the current manager has been the portfolio manager for the fund. For funds with more than one manager, we use the tenure of the manager who has been with the fund the longest. All data are collected from Morningstar except for the management fee which is collected from the CRSP Mutual Fund database. We also include the monthly return (RET), volatility (VOL), and fund flow (FLOW) estimated over the previous 12 months to control for the recent performance of funds. To ease the interpretation of the results, all variables are cross-sectionally standardised to have a mean of zero and a standard deviation of one.

We use the Fama-MacBeth (1973) regression methodology to estimate the sensitivity of a fund's tail risk beta in month $t+1$ on the fund's characteristics as measured in month $t$. Specifically, we estimate the following regression equation:

$$
\beta_{i, t+1}=\alpha+\zeta V_{i, t}+\varepsilon_{i, t+1}
$$

where $\beta_{i, t+1}$ is fund's $i$ tail risk beta in month $t+1, V_{i, t}$ is the vector of the fund characteristics, $\zeta$ is the vector of coefficients to be estimated, and $\varepsilon_{i, t+1}$ is an error term. Table 7 reports the estimated cross-sectional coefficients with Newey-West (1987) corrected standard errors over the sample period from January 1985 to September 2015. Column 1 reports the coefficient estimates for the natural logarithm of size, age, and the corporate governance score. Column 2

\footnotetext{
${ }^{19}$ Sustainalytics is an independent corporate governance research, ratings and analysis firm that provides in-depth governance reports for over 4,000 companies.
} 
reports the coefficient estimates for the management fee, manager tenure, and managerial ownership. And column 3 reports the coefficient estimates for all fund characteristics in our analysis.

$$
\text { ***Insert Table } 7 \text { around here*** }
$$

The estimation of the first model shows a strong negative relation between tail risk loadings and the size and age of the fund, as well as its corporate governance score. The estimated coefficients are all statistically significant at the $1 \%$ level, and strongly suggest that funds susceptible to tail risk tend to be small, young, and of poor corporate governance. These results are consistent with prior literature on the risk-taking behavior of fund managers (see, e.g., Kempf, Ruenzi, and Thiele (2009), Koski and Pontiff (1999), Chevalier and Ellison (1997), Brown, Harlow, and Starks (1996)) and have an intuitive interpretation. In particular, small and young funds have an incentive to establish a record of high returns in order to make the rankings and to attract new flows of capital. A tempting way of doing so is to load up on investments with high tail risk susceptibility. As funds grow larger and older, the incentives to invest in high tail risk assets diminish, leading to the negative size and age coefficients that we find. The results also indicate that funds with poor corporate governance tend to have high exposure to tail risk, probably due to the exacerbation of the principal-agent problem that can induce fund managers to invest in high tail risk assets, which have high expected returns that may lead to inflows of fresh capital and help them to increase their earnings. On the other hand, the managers of better governed funds are more closely monitored and more easily replaced, and, hence, more reluctant to increase their exposure to tail risk. 
The estimation of the second model reveals a strong positive relation between tail risk loadings and management fee, and a strong negative relation between tail risk loadings and managerial ownership; the estimated coefficients are statistically significant at the $1 \%$, and $5 \%$ levels, respectively. Consistent with the predictions of Huang, Sialm, and Zhang (2011), Koski and Pontiff (1999), Brown et al., (1996), and Chevalier and Ellison (1997), we find that the higher the management fee, the stronger the incentives of the fund managers to invest in high tail risk assets in order to increase the expected return of the fund and their potential to reap a high reward. Our results also indicate that fund managers who risk their own capital are less likely to take on tail risk due to the fear of suffering large personal losses, which is consistent with Khorana et al., (2007), and Ma and Tang (2017).

The estimation of the third model includes all available fund characteristics. The estimated coefficients of the fund size and age remain negative and statistically significant, but the coefficient for the corporate governance score becomes statistically insignificant. Consistent with Khorana et al. (2007), this is perhaps not surprising because most of the dimensions of the corporate governance score we employ in our study are not directly related to the day-to-day management of the fund's portfolio and therefore are less likely to affect the manager's risktaking incentives strongly. Instead we continue to observe a negative and statistically significant relation between tail risk betas and managerial ownership. Further, the level of the management fee remains an important determinant of the fund's susceptibility to tail risk. The relation between tail risk loadings and the manager's tenure remains statistically insignificant. These results also have economic significance. For example, a one standard deviation increase in the management fee predicts a $13.8 \%$ standard deviation increase in tail risk, while a one standard deviation increase in managerial ownership and natural logarithm of size predict a $17.2 \%$ and 
$8.0 \%$ standard deviation decrease in tail risk, respectively. Overall, our results indicate that funds susceptible to tail risk tend to be small, young, have high management fees, and have managers who do not risk their own capital. These characteristics explain as much as $30 \%$ of the crosssectional variation in the tail risk betas.

\section{Conclusion}

In this paper we investigate the pricing impact of tail risk on actively managed equity mutual funds. In particular, we examine the premise that funds with high loadings on tail risk receive a lower valuation from risk averse investors and thus have higher expected returns compared to funds with low loadings on tail risk. Using the time varying aggregate tail risk measure of Kelly and Jiang (2014), we show that the common tail risk in actively managed equity mutual funds helps to explain the cross-sectional variation in fund returns. We find that the estimates of the tail risk premium are statistically and economically significant, with funds with high exposure to tail risk outperforming funds with low exposure to tail risk by $4.4 \%$ per annum. The tail risk premium persists even when we control for commonly used risk factors. Our results are also robust to a number of important fund characteristics that comprise the benchmark alpha, fund size, expense ratio, turnover ratio, tracking error, management fee, and managerial ownership. We also find that funds susceptible to tail risk tend to be small, young, have high management fees, and have managers who do not risk their own capital. These findings are consistent with the risk taking behavior of fund managers as a response to managerial incentives. Overall, our results support the view that the superior performance of fund managers might be due more to their high 
exposure to tail risk rather than their stock-picking ability and, therefore, could provide a different perspective in explaining and evaluating the performance of mutual funds. 


\section{References}

Adam, T. R., and L. Klipper. "Fire-Sale Cascades: Empirical Evidence from the Mutual Fund Industry.” EFA Meetings Paper (2017).

Agarwal, V.; S. Ruenzi; and F. Weigert. "Tail Risk in Hedge Funds: A Unique View from Portfolio Holdings.” Journal of Financial Economics, forthcoming.

Ang, A.; J. Chen; and Y. Xing. "Downside Risk." Review of Financial Studies, 19 (2006) 11911239.

Badrinath, S. G., and S. Wahal. "Momentum Trading by Institutions." Journal of Finance, 57 (2002), 2449-2478.

Bali, T.; K. O. Demirtas; and H. Levy. "Is there an Intertemporal Relation between Downside Risk and Expected Returns." Journal of Financial and Quantitative Analysis, 44 (2009), 883909.

Barro, R. J. "Rare Disasters and Asset Markets in the Twentieth Century." Quarterly Journal of Economics, 121 (2006), 823-866.

Barroso, P., and P. Santa-Clara. "Momentum has its Moments. ” Journal of Financial Economics, 116 (2015), 111-120.

Berk, J. B., and J. H. van Binsbergen. "Measuring Skill in the Mutual Fund Industry." Journal of Financial Economics, 118 (2015), 1-20.

Berkman, H.; B. Jacobsen; and J. B. Lee. "Time-varying Rare Disaster Risk and Stock Returns." Journal of Financial Economics, 101 (2011), 313-332.

Bloom, N. “The Impact of Uncertainty Shocks.” Econometrica, 77 (2009), 623-65.

Bollerslev, T., and V. Todorov. "Tails, Fears, and Risk Premia." Journal of Finance, 66 (2011), 2165-2211.

Brown, K. C.; W. V. Harlow; and L. T. Starks. "Of Tournaments and Temptations: An Analysis of Managerial Incentives in the Mutual Fund Industry." Journal of Finance, 51 (1996), 85-110.

Brown, N. C.; K. D. Wei; and R. Wermers. "Analyst Recommendations, Mutual Fund Herding, and Overreaction in Stock Prices.” Management Science, 60 (2014), 1-20.

Carhart, M. "On Persistence in Mutual Fund Performance.” Journal of Finance, 52 (1997), 5782.

Chang, B. Y.; P. Christoffersen; and K. Jacobs. "Market Skewness Risk and the Cross Section of Stock Returns.” Journal of Financial Economics, 107 (2013), 46-68.

Chen, J.; H. Hong; M. Huang; and J. D. Kubik. "Does Fund Size Erode Mutual Fund Performance? The Role of Liquidity and Organization." American Economic Review, 94 (2004), 1276-1302. 
Chevalier, J., and G. Ellison. "Risk Taking by Mutual Funds as a Response to Incentives." Journal of Political Economy, 105 (1997), 1167-1200.

Coval, J., and E. Stafford. "Asset Fire Sales (and Purchases) in Equity Markets." Journal of Financial Economics, 86 (2007), 479-512.

Daniel, K., and T. J. Moskowitz. "Momentum Crashes." Journal of Financial Economics, 122 (2016), 221-247.

Daniel, K.; R. Jagannathan; and S. Kim. "Tail Risk in Momentum Strategy Returns.” Working paper, Columbia University (2017).

Dass, N.; M. Massa; and R. Patgiri. "Mutual Funds and Bubbles: The Surprising Role of Contractual Incentives." Review of Financial Studies, 21 (2008), 51-99.

De Long, J. B.; A. Shleifer; L. H. Summers; and R. J. Waldmann. "Positive Feedback Investment Strategies and Destabilizing Rational Speculation." Journal of Finance, 45 (1990), 379-395.

Del Guercio, D., and J. Reuter. "Mutual Fund Performance and the Incentive to Generate Alpha." Journal of Finance, 69 (2014), 1673-1704.

Edelen, R. "Investor Flows and the Assessed Performance of Open-end Fund Managers." Journal of Financial Economics, 53 (1999), 439-466.

Fama, E. F., and K. R. French. "Common Risk Factors in the Returns on Stocks and Bonds." Journal of Financial Economics, 33 (1993), 3-56.

Fama, E. F., and K. R. French. "Luck Versus Skill in the Cross Section of Mutual Fund Returns.” Journal of Finance, 65 (2010), 1915-1947.

Fama, E. F., and J. D. MacBeth. "Risk, Return, and Equilibrium: Empirical Tests." Journal of Political Economy, 81 (1973), 607-636.

Farago, A., and R. Tédongap. "Downside Risks and the Cross-Section of Asset Returns." Journal of Financial Economics, forthcoming.

Gabaix, X. "Power Laws in Economics and Finance." Annual Review of Economics, 1 (2009), 255-293.

Gabaix, X. "Variable Rare Disasters: An Exactly Solved Framework for Ten Puzzles in MacroFinance." Quarterly Journal of Economics, 127 (2012), 645-700.

Gabaix, X.; P. Gopikrishnan; V. Plerou; and H. Stanley. "Institutional Investors and Stock Market Volatility." Quarterly Journal of Economics, 121 (2006), 461-504.

Gourio, F. "Disaster Risk and Business Cycles." American Economic Review, 102 (2012), 27342766.

Grinblatt, M., and S. Titman. "Mutual Fund Performance: An Analysis of Quarterly Portfolio Holdings”, Journal of Business, 62 (1989), 393- 416. 
Grinblatt, M., and S. Titman. "The Persistence of Mutual Fund Performance." Journal of Finance, 47 (1992), 1977-1984.

Grinblatt, M.; S. Titman; and R. Wermers. "Momentum Investment Strategies, Portfolio Performance and Herding: A Study of Mutual Fund Behavior." American Economic Review, 85 (1995), 1088-1111.

Gruber, M. J. “Another Puzzle: The Growth of Actively Managed Mutual Funds.” Journal of Finance, 51 (1996), 783-810.

Hill, B. "A Simple General Approach to Inference about the Tail of a Distribution." Annals of Statistics, 3 (1975), 1163-74.

Huang, J.; C. Sialm; and H. Zhang. "Risk Shifting and Mutual Fund Performance." Review of Financial Studies, 24 (2011), 2575-1616.

Investment Company Institute. "Investment Company Factbook: A Review of Trends and Activities in the U.S. Investment Company Industry." 55th Edition (2016), Investment Company Institute.

Jensen, M., and W. Meckling. "Theory of the Firm: Managerial Behavior, Agency Costs, and Ownership Structure.” Journal of Financial Economics, 3 (1976), 305-360.

Kelly, B. “The Dynamic Power Law Model.” Extremes 17 (2014), 557-583.

Kelly, B., and H. Jiang. "Tail Risk and Asset Prices.” Review of Financial Studies, 27 (2014), 2841-2871.

Kempf, A.; S. Ruenzi; and T. Thiele. "Employment Risk, Compensation Incentives, and Managerial Risk Taking: Evidence from the Mutual Fund Industry." Journal of Financial Economics, 92 (2009), 92-108.

Khorana, A.; H. Servaes; and L. Wedge. "Portfolio Manager Ownership and Fund Performance." Journal of Financial Economics, 85 (2007), 179-204.

Koski, J. L., and J. Pontiff. "How Are Derivatives Used? Evidence from the Mutual Fund Industry." Journal of Finance, 54 (1999), 791-816.

Lakonishok, J.; A. Shleifer; R. W. Vishny. "The Impact of Institutional Trading on Stock Prices." Journal of Financial Economics, 32 (1992), 23-43.

Lettau, M.; M. Maggiori; and M. Weber. "Conditional Risk Premia in Currency Markets and other Asset Classes.” Journal of Financial Economics, 114 (2014), 197-225.

Ma, L., and Y. Tang. "Portfolio Manager Ownership and Mutual Fund Risk Taking." AFA Meetings Paper (2013).

Morningstar Direct. Glossary (2017), http://www.morningstar.co.uk/uk/glossary/E.aspx 
Newey, W., and K. West. "A Simple, Positive Semi-definite, Heteroskedasticity and Autocorrelation Consistent Covariance Matrix.” Econometrica, 55 (1987), 703-08.

Newey, W., and K. West. "Automatic Lag Selection in Covariance Matrix Estimation.” Review of Economic Studies, 61 (1994), 631-653.

Nofsinger, J., and R. Sias. "Herding and Feedback Trading by Institutional and Individual Investors. ” Journal of Finance, 54 (1999), 2263-2295.

Pastor, L., and R. F. Stambaugh. "Liquidity Risk and Expected Stock Returns.” Journal of Political Economy, 111(2003), 642-685.

Pastor, L., and R. F. Stambaugh. "On the Size of the Active Management Industry." Journal of Political Economy, 120 (2012), 740-781.

Rakowski, D. "Fund Flow Volatility and Performance." Journal of Financial and Quantitative Analysis, 45 (2010), 223-237.

Roll, R. “A Mean/Variance Analysis of Tracking Error.” Journal of Portfolio Management, 18 (1992), 13-22.

Roy, A. D. "Safety First and the Holding of Assets.” Econometrica, 20 (1952), 431-449.

Sias, R. W. “Institutional Herding.” Review of Financial Studies, 17 (2004), 165-206.

Tsai, J., and J. A. Wachter. "Rare Booms and Disasters in a Multisector Endowment Economy." Review of Financial Studies, 29 (2016), 1113-1169.

Wachter, J. A. "Can Time-Varying Risk of Rare Disasters Explain Aggregate Stock Market Volatility?” Journal of Finance, 68 (2013), 987-1035.

Weigert, F. "Crash Aversion and the Cross-Section of Expected Stock Returns Worldwide." Review of Asset Pricing Studies, 6 (2016), 135-178.

Welch, I. "The Time-varying Importance of Disaster Risk." Financial Analysts Journal, 72 (2016), 14-30.

Wermers, R. "Mutual Fund Herding and the Impact on Stock Prices." Journal of Finance, 54 (1999), 581-622.

Wermers, R. "Mutual Fund Performance: An Empirical Decomposition into Stock-Picking Talent, Style, Transactions Costs, and Expenses." Journal of Finance, 55 (2000), 1655-1695. 


\section{Table 1. Summary statistics for the sample of all mutual funds}

This table presents the averages of the annual cross-sectional average attributes from January 1985 to September 2015. The average assets under management (AUM) (\$millions) is the average of the month-end net assets for all funds in a group. The average annual expense ratio (\%) is the annual average percentage of assets paid for interest expense, operating expenses and management fees for all funds in a group; it typically includes: interest and dividends, accounting, administrator, advisor, audit, board of directors, custodial, distribution (12b-1), legal, organizational, professional, registration, shareholder reporting, sub-advisor, and transfer agency. Due to the unavailability of annual data from 1985 to 1995 , this entry is based on the average annual expense ratios from 1995 to 2014. The average turnover ratio (\%) gives the average percentage of the portfolios' holdings that have changed over the past year for all funds in a group. All data come from Morningstar.

Average annual attributes, 1985-2015

\begin{tabular}{llllllll}
\hline & $\begin{array}{l}\text { Total } \\
\text { number of } \\
\text { funds }\end{array}$ & $\begin{array}{l}\text { Average } \\
\text { number } \\
\text { of funds }\end{array}$ & $\begin{array}{l}\text { Minimum } \\
\text { average } \\
\text { number of } \\
\text { funds }\end{array}$ & $\begin{array}{l}\text { Maximum } \\
\text { average } \\
\text { number of } \\
\text { funds }\end{array}$ & $\begin{array}{l}\text { Average } \\
\text { AUM (\$ } \\
\text { millions) }\end{array}$ & $\begin{array}{l}\text { Average Expense } \\
\text { Ratio (\%) }\end{array}$ & $\begin{array}{l}\text { Average Turnover } \\
\text { Ratio (\%) }\end{array}$ \\
\hline All funds & 1,750 & 962 & 158 & 1,731 & $1,201.77$ & 1.16 & 80.12 \\
\hline By equity style & & & & & & & \\
Large-cap Value & 270 & 154 & 27 & 267 & $1,477.97$ & 1.21 & 62.91 \\
Large-cap Blend & 310 & 171 & 31 & 305 & $1,491.85$ & 1.23 & 67.80 \\
Large-cap Growth & 383 & 226 & 63 & 379 & $1,943.84$ & 1.26 & 85.14 \\
Mid-cap Value & 85 & 42 & 4 & 84 & 911.25 & 1.20 & 76.35 \\
Mid-cap Blend & 85 & 42 & 3 & 85 & 466.32 & 1.66 & 110.88 \\
Mid-cap Growth & 166 & 94 & 15 & 164 & 753.76 & 1.28 & 108.27 \\
Small-cap Value & 90 & 45 & 3 & 90 & 394.67 & 1.49 & 59.94 \\
Small-cap Blend & 162 & 80 & 6 & 161 & 408.05 & 1.27 & 68.76 \\
Small-cap Growth & 199 & 107 & 7 & 197 & 375.51 & 1.63 & 93.42 \\
\hline
\end{tabular}




\section{Table 2. Summary statistics of the monthly fund returns}

This table presents the summary statistics for the gross monthly returns for an equal-weighted portfolio of all funds as well as the equal-weighted portfolios based on Morningstar's nine different equity style classifications. 'Return' denotes the average monthly gross return. 'Std.Dev.', 'Min.', 'Max.', 'Skewness', and 'Kurtosis' denote the average standard deviation, minimum value, maximum value, skewness, and kurtosis of the gross monthly returns, respectively. 'Jarque-Bera' denotes the Jarque and Bera normality test statistic. The $p$-values of the Jarque and Bera test are given in parentheses. The gross monthly returns start in January 1985 and end in September 2015. All data come from Morningstar.

\begin{tabular}{llllllll}
\hline & \multicolumn{7}{c}{ Average annual attributes, January 1985 to September 2015 } \\
\hline & Return (\%) & Std. Dev. (\%) & Min. (\%) & Max. (\%) & Skewness & Kurtosis & Jarque-Bera \\
\hline All funds & 1.06 & 4.57 & -19.13 & 24.90 & -0.131 & 3.697 & $1045.55(0.000)$ \\
\hline By equity style & & & & & & & \\
$\quad$ Large-cap Value & 0.95 & 3.80 & -14.06 & 15.23 & -0.214 & 3.734 & $205.45(0.000)$ \\
Large-cap Blend & 0.98 & 4.00 & -13.66 & 15.46 & -0.185 & 3.452 & $203.71(0.000)$ \\
Large-cap Growth & 1.04 & 4.54 & -15.07 & 18.96 & -0.090 & 3.387 & $213.00(0.000)$ \\
Mid-cap Value & 1.11 & 4.35 & -11.50 & 12.84 & -0.198 & 3.217 & $37.93(0.000)$ \\
Mid-cap Blend & 1.08 & 4.76 & -13.98 & 18.01 & -0.066 & 4.196 & $149.15(0.000)$ \\
Mid-cap Growth & 1.17 & 5.18 & -15.50 & 17.46 & -0.128 & 3.312 & $133.53(0.000)$ \\
Small-cap Value & 1.10 & 4.81 & -12.71 & 15.02 & -0.228 & 3.321 & $44.39(0.000)$ \\
Small-cap Blend & 1.06 & 4.66 & -12.61 & 13.88 & -0.256 & 3.133 & $68.21(0.000)$ \\
Small-cap Growth & 1.16 & 5.55 & -16.34 & 19.89 & -0.147 & 3.239 & $79.07(0.000)$
\end{tabular}




\section{Table 3. Average out-of-sample monthly returns and portfolio alphas for fund portfolios sorted on tail risk betas}

This table presents the average out-of-sample monthly returns of quintile portfolios formed on tail risk betas. The portfolios are rebalanced every 6- and 12- months. The tail risk betas are estimated by running predictive regressions of the monthly returns of each fund over the previous five years (i.e., 60 monthly returns) on the aggregate tail risk. The table also reports the monthly alphas obtained from regressions of the monthly returns of fund quintile portfolios on CAPM that controls for market risk; on the Fama and French's three-factor model (FF) that also controls for size, and book-to-market; on Carhart's four-factor model (FF+Mom) that also controls for momentum; and on Pastor and Stambaugh's five-factor model (FF+Mom+Liq) that also controls for liquidity. Panel A (Panel B) reports the equal-weighted (valueweighted) average monthly returns for the out-of-sample 12- and 6-month holding periods. The average monthly returns and alphas for all quintile portfolios are statistically significant. The High-Low denotes a zero net investment portfolio that is long in quintile portfolio 5 (i.e., high tail risk beta) and short in quintile portfolio 1 (i.e., low tail risk beta). The last column reports the $t$-statistics with Newey-West (1987) corrected standard errors for the High-Low portfolio, with the optimal number of lags determined following Newey and West (1994). As a proxy for the risk-free rate we use the one-month T-bill rate. As a proxy of the market return, we use the monthly return of the value-weighted portfolio of all NYSE, AMEX, and NASDAQ stocks with a share code of 10 and 11 in CRSP.

\begin{tabular}{lccccccc}
\hline Tail risk beta & Low $=1$ & 2 & 3 & 4 & High=5 & High-Low $t$-stat \\
\hline Panel A. Equal-weighted portfolios & & & & \\
\hline 12-month returns & & & & & & & \\
Average return & 0.82 & 0.90 & 0.99 & 1.04 & 1.19 & 0.37 & 2.376 \\
CAPM alpha & -0.10 & 0.03 & 0.13 & 0.18 & 0.31 & 0.41 & 2.423 \\
FF alpha & -0.09 & 0.00 & 0.07 & 0.10 & 0.19 & 0.28 & 2.341 \\
FF+Mom alpha & -0.10 & 0.01 & 0.08 & 0.10 & 0.19 & 0.29 & 2.503 \\
FF+Mom+Liq alpha & -0.10 & 0.01 & 0.08 & 0.10 & 0.19 & 0.29 & 2.496 \\
\hline
\end{tabular}

\section{Continued}


Table 3. Continued

\begin{tabular}{lccccccc}
\hline Tail risk beta & Low=1 & 2 & 3 & 4 & High=5 & High-Low $t$-stat \\
\hline 6-month return & & & & & & & \\
Average return & 0.81 & 0.86 & 0.94 & 1.00 & 1.11 & 0.30 & 1.769 \\
CAPM alpha & -0.06 & 0.03 & 0.12 & 0.18 & 0.27 & 0.33 & 1.752 \\
FF alpha & -0.04 & 0.01 & 0.07 & 0.11 & 0.18 & 0.22 & 1.607 \\
FF+Mom alpha & -0.05 & 0.01 & 0.08 & 0.12 & 0.18 & 0.23 & 1.737 \\
FF+Mom+Liq alpha & -0.05 & 0.01 & 0.08 & 0.12 & 0.18 & 0.23 & 1.735 \\
\hline
\end{tabular}

Panel B. Value-weighted portfolios

\section{2-month returns}

Average return

CAPM alpha

FF alpha

FF+Mom alpha

$\mathrm{FF}+\mathrm{Mom}+\mathrm{Liq}$ alpha

$\begin{array}{lllllll}0.78 & 0.89 & 0.93 & 1.02 & 1.11 & 0.34 & 2.151 \\ -0.15 & 0.05 & 0.10 & 0.16 & 0.24 & 0.38 & 2.269 \\ -0.13 & 0.02 & 0.04 & 0.09 & 0.15 & 0.27 & 2.247 \\ -0.13 & 0.02 & 0.07 & 0.10 & 0.14 & 0.27 & 2.328 \\ -0.13 & 0.02 & 0.07 & 0.10 & 0.14 & 0.27 & 2.314\end{array}$

\section{Continued}


Table 3. Continued

\begin{tabular}{|c|c|c|c|c|c|c|c|}
\hline Tail risk beta & Low $=1$ & 2 & 3 & 4 & High $=5$ & High-Low & $t$-stat \\
\hline \multicolumn{8}{|l|}{ 6-month return } \\
\hline Average return & 0.77 & 0.86 & 0.89 & 0.96 & 1.06 & 0.30 & 1.798 \\
\hline CAPM alpha & -0.11 & 0.05 & 0.10 & 0.15 & 0.23 & 0.34 & 1.811 \\
\hline FF alpha & -0.08 & 0.02 & 0.04 & 0.07 & 0.16 & 0.24 & 1.781 \\
\hline $\mathrm{FF}+\mathrm{Mom}$ alpha & -0.09 & 0.02 & 0.07 & 0.08 & 0.15 & 0.24 & 1.817 \\
\hline FF+Mom+Liq alpha & -0.09 & 0.02 & 0.06 & 0.08 & 0.15 & 0.24 & 1.803 \\
\hline
\end{tabular}




\section{Table 4. Average out-of-sample monthly returns for fund portfolios double-sorted on tail risk betas and equity styles}

This table contains the average out-of-sample monthly returns of the equal- and value-weighted fund quintile portfolios formed by independent sorts of the funds on tail risk betas and Morningstar's equity style classifications. The portfolios are rebalanced every 12 months. The tail risk betas are estimated by running predictive regressions of the monthly returns of each fund over the previous five years (i.e., 60 monthly returns) on the aggregate tail risk. The average monthly returns for all quintile portfolios are statistically significant at commonly used significance levels. The High-Low denotes a zero net investment portfolio that is long in quintile portfolio 5 (i.e., high tail risk beta) and short in quintile portfolio 1 (i.e., low tail risk beta). The associated $t$-statistics with Newey-West (1987) corrected standard errors for the High-Low portfolio are given in parentheses, with the optimal number of lags determined following Newey and West (1994).

\begin{tabular}{lccccccccccccc}
\hline Tail risk beta & Low=1 & 2 & 3 & 4 & High=5 & High-Low & Low=1 & 2 & 3 & 4 & High=5 & High-Low \\
\hline By equity Style & \multicolumn{9}{c}{ Equal-weighted portfolios } & & \multicolumn{3}{c}{ Value-weighted portfolios } \\
\hline Large-cap Value & 1.11 & 1.16 & 1.14 & 1.25 & 1.44 & $0.33(1.398)$ & 1.15 & 1.17 & 1.03 & 1.17 & 1.64 & $0.49(1.813)$ \\
Large-cap Blend & 1.19 & 1.14 & 1.22 & 1.29 & 1.30 & $0.11(1.124)$ & 1.17 & 1.09 & 1.22 & 1.29 & 1.38 & $0.21(1.174)$ \\
Large-cap Growth & 1.35 & 1.29 & 1.32 & 1.35 & 1.40 & $0.06(0.919)$ & 1.35 & 1.29 & 1.29 & 1.30 & 1.44 & $0.09(0.923)$ \\
Mid-cap Value & 1.26 & 1.31 & 1.34 & 1.37 & 1.40 & $0.13(0.981)$ & 1.32 & 1.40 & 1.39 & 1.40 & 1.45 & $0.13(1.351)$ \\
Mid-cap Blend & 1.09 & 1.32 & 1.34 & 1.33 & 1.24 & $0.15(1.091)$ & 1.41 & 1.25 & 1.47 & 1.51 & 1.37 & $0.17(1.024)$ \\
Mid-cap Growth & 1.33 & 1.33 & 1.42 & 1.44 & 1.39 & $0.06(0.449)$ & 1.26 & 1.35 & 1.39 & 1.39 & 1.42 & $-0.04(-0.197)$ \\
Small-cap Value & 1.29 & 1.30 & 1.33 & 1.25 & 1.33 & $0.03(0.260)$ & 1.31 & 1.35 & 1.32 & 1.18 & 1.33 & $0.03(0.180)$ \\
Small-cap Blend & 1.29 & 1.35 & 1.33 & 1.39 & 1.41 & $0.12(0.993)$ & 1.20 & 1.33 & 1.34 & 1.37 & 1.34 & $0.14(1.434)$ \\
Small-cap Growth & 1.21 & 1.42 & 1.36 & 1.45 & 1.46 & $0.25(1.793)$ & 1.21 & 1.43 & 1.31 & 1.47 & 1.39 & $0.18(1.785)$ \\
\hline
\end{tabular}




\section{Table 5. Average out-of-sample monthly returns for fund portfolios formed on tail risk betas and fund characteristics}

This table reports the average out-of-sample monthly returns for the equal- and value-weighted portfolios formed by independent sorts of the funds on tail risk betas and their characteristics. The portfolios are rebalanced every 12-months. The characteristics are benchmark alphas (BNCH_ALPHA), fund size (SIZE), expense ratio (EXP_RATIO), turnover ratio (TURN_RATIO), tracking error (TR_ERROR), management fee (MNG_FEE), and managerial ownership (MNG_OWN). The sample period is from January 1985 to September 2015. The tail risk betas are estimated by running predictive regressions of the monthly returns of each fund over the previous five years (i.e., 60 monthly returns) on the aggregate tail risk. Sorting on tail risk betas, and benchmark alpha, fund size, turnover ratio, tracking error, and managerial ownership takes place monthly, and for the expense ratio and management fee the sorting is annually. For all characteristics, we sort funds in quintiles. The average monthly returns for all quintile portfolios are statistically significant at commonly used significance levels. The High-Low denotes a zero net investment portfolio that is long in quintile portfolio 5 (i.e., high tail risk beta) and short in quintile portfolio 1 (i.e., low tail risk beta). The associated $t$-statistics with Newey-West (1987) corrected standard errors for the High-Low portfolio are in parentheses, with the optimal number of lags determined following Newey and West (1994).

\begin{tabular}{|c|c|c|c|c|c|c|c|c|c|c|c|c|}
\hline Tail risk beta & Low $=1$ & 2 & 3 & 4 & High $=5$ & High-Low & Low $=1$ & 2 & 3 & 4 & High $=5$ & High-Low \\
\hline $\begin{array}{l}\text { By fund } \\
\text { characteristics }\end{array}$ & \multicolumn{6}{|c|}{ Equal-weighted portfolios } & \multicolumn{6}{|c|}{ Value-weighted portfolios } \\
\hline \multicolumn{13}{|c|}{$\underline{B N C H A L P H A}$} \\
\hline Low $=1$ & 0.71 & 0.75 & 0.91 & 0.89 & 1.05 & $0.34(1.712)$ & 0.63 & 0.62 & 0.80 & 0.92 & 1.07 & $0.44(1.877)$ \\
\hline 2 & 0.71 & 0.80 & 0.85 & 0.90 & 0.98 & $0.27(1.365)$ & 0.74 & 0.87 & 0.84 & 0.88 & 1.00 & $0.26(1.255)$ \\
\hline 3 & 0.80 & 0.85 & 0.89 & 0.91 & 1.01 & $0.22(1.144)$ & 0.75 & 0.83 & 0.85 & 0.90 & 0.90 & $0.15(0.792)$ \\
\hline 4 & 0.81 & 0.88 & 0.91 & 0.97 & 1.13 & $0.32(1.763)$ & 0.71 & 0.85 & 0.82 & 1.01 & 1.05 & $0.34(1.691)$ \\
\hline High $=5$ & 0.99 & 0.96 & 1.04 & 1.02 & 1.16 & $0.17(0.880)$ & 0.91 & 0.88 & 0.95 & 0.92 & 1.04 & $0.12(0.655)$ \\
\hline
\end{tabular}

\section{Continued}


Table 5. Continued

\begin{tabular}{|c|c|c|c|c|c|c|c|c|c|c|c|c|}
\hline Tail risk beta & Low $=1$ & 2 & 3 & 4 & High $=5$ & High-Low & Low $=1$ & 2 & 3 & 4 & High $=5$ & High-Low \\
\hline \multicolumn{13}{|l|}{$\underline{S I Z E}$} \\
\hline Small $=1$ & 0.85 & 0.94 & 1.03 & 0.98 & 1.25 & $0.40(2.269)$ & 0.91 & 0.92 & 1.03 & 0.95 & 1.25 & $0.34(1.900)$ \\
\hline 2 & 0.87 & 0.88 & 0.98 & 1.04 & 1.25 & 0.38 (1.979) & 0.86 & 0.88 & 0.98 & 1.05 & 1.25 & $0.39(2.038)$ \\
\hline 3 & 0.76 & 0.89 & 1.06 & 1.14 & 1.11 & $0.35(1.987)$ & 0.76 & 0.88 & 1.06 & 1.15 & 1.12 & $0.35(2.010)$ \\
\hline 4 & 0.83 & 0.92 & 0.95 & 1.01 & 1.14 & $0.32(1.683)$ & 0.83 & 0.92 & 0.93 & 1.02 & 1.13 & $0.30(1.577)$ \\
\hline Large $=5$ & 0.80 & 0.88 & 0.94 & 1.03 & 1.15 & $0.35(1.836)$ & 0.77 & 0.89 & 0.92 & 1.01 & 1.11 & $0.34(1.746)$ \\
\hline \multicolumn{13}{|l|}{$\underline{E X P R A T I O}$} \\
\hline Low $=1$ & 0.69 & 0.76 & 0.87 & 0.90 & 1.02 & $0.33(1.368)$ & 0.71 & 0.75 & 0.81 & 0.89 & 1.05 & $0.34(1.484)$ \\
\hline 2 & 0.66 & 0.78 & 0.77 & 0.88 & 1.01 & $0.35(1.475)$ & 0.58 & 0.76 & 0.74 & 0.90 & 0.99 & $0.41(1.629)$ \\
\hline 3 & 0.72 & 0.75 & 0.85 & 0.94 & 1.04 & $0.32(1.441)$ & 0.70 & 0.68 & 0.79 & 0.95 & 0.99 & $0.29(1.125)$ \\
\hline 4 & 0.74 & 0.79 & 0.92 & 0.90 & 1.05 & $0.32(1.428)$ & 0.56 & 0.58 & 1.00 & 0.91 & 1.01 & $0.45(2.043)$ \\
\hline High $=5$ & 0.65 & 0.80 & 0.99 & 0.94 & 1.15 & $0.50(2.179)$ & 0.67 & 0.71 & 0.89 & 0.88 & 1.00 & $0.33(1.434)$ \\
\hline
\end{tabular}

\section{Continued}


Table 5. Continued

\begin{tabular}{|c|c|c|c|c|c|c|c|c|c|c|c|c|}
\hline Tail risk beta & Low $=1$ & 2 & 3 & 4 & High $=5$ & High-Low & Low $=1$ & 2 & 3 & 4 & High $=5$ & High-Low \\
\hline \multicolumn{13}{|l|}{$\underline{T U R N} R A T I O$} \\
\hline Low $=1$ & 0.86 & 0.87 & 0.93 & 1.02 & 1.15 & $0.28(1.618)$ & 0.83 & 0.88 & 0.91 & 1.06 & 1.19 & $0.36(2.225)$ \\
\hline 2 & 0.79 & 0.86 & 1.00 & 1.04 & 1.19 & $0.40(2.047)$ & 0.73 & 0.84 & 0.91 & 1.01 & 1.22 & $0.49(2.665)$ \\
\hline 3 & 0.82 & 0.93 & 0.99 & 1.04 & 1.16 & $0.35(1.710)$ & 0.78 & 0.91 & 0.93 & 1.00 & 1.09 & $0.30(1.348)$ \\
\hline 4 & 0.84 & 0.90 & 0.98 & 1.02 & 1.18 & $0.35(1.548)$ & 0.90 & 0.83 & 0.87 & 1.03 & 1.14 & $0.25(1.123)$ \\
\hline High $=5$ & 0.82 & 0.98 & 1.04 & 1.11 & 1.33 & $0.51(3.418)$ & 0.78 & 0.94 & 0.99 & 1.12 & 1.15 & $0.37(2.250)$ \\
\hline \multicolumn{13}{|l|}{$\underline{T R E R R O R}$} \\
\hline Small=1 & 0.44 & 0.52 & 0.52 & 0.63 & 0.87 & $0.43(2.394)$ & 0.42 & 0.48 & 0.49 & 0.61 & 0.78 & $0.36(2.434)$ \\
\hline 2 & 0.48 & 0.53 & 0.61 & 0.69 & 0.82 & $0.34(1.788)$ & 0.50 & 0.61 & 0.61 & 0.70 & 0.84 & $0.35(1.681)$ \\
\hline 3 & 0.50 & 0.63 & 0.74 & 0.85 & 1.06 & $0.56(2.325)$ & 0.47 & 0.65 & 0.79 & 0.87 & 1.10 & $0.63(2.497)$ \\
\hline 4 & 0.62 & 0.64 & 0.94 & 0.93 & 1.00 & $0.37(1.595)$ & 0.57 & 0.48 & 0.90 & 0.95 & 0.91 & $0.34(1.090)$ \\
\hline Large $=5$ & 0.51 & 0.78 & 0.90 & 0.78 & 0.96 & $0.45(1.421)$ & 0.39 & 0.77 & 0.78 & 0.67 & 0.85 & $0.46(1.610)$ \\
\hline
\end{tabular}

\section{Continued}


Table 5. Continued

\begin{tabular}{|c|c|c|c|c|c|c|c|c|c|c|c|c|}
\hline Tail risk beta & Low $=1$ & 2 & 3 & 4 & High $=5$ & High-Low & Low $=1$ & 2 & 3 & 4 & High $=5$ & High-Low \\
\hline \multicolumn{13}{|l|}{$\underline{M N G \quad F E E}$} \\
\hline $\mathrm{Low}=1$ & 0.45 & 0.52 & 0.66 & 0.71 & 0.90 & $0.45(2.602)$ & 0.40 & 0.52 & 0.59 & 0.66 & 0.85 & $0.45(2.318)$ \\
\hline 2 & 0.43 & 0.55 & 0.66 & 0.76 & 0.99 & $0.56(2.674)$ & 0.40 & 0.47 & 0.65 & 0.76 & 0.93 & $0.54(2.681)$ \\
\hline 3 & 0.42 & 0.49 & 0.66 & 0.75 & 0.98 & $0.56(2.501)$ & 0.34 & 0.49 & 0.64 & 0.72 & 1.00 & $0.65(2.770)$ \\
\hline 4 & 0.39 & 0.50 & 0.68 & 0.74 & 0.91 & $0.52(2.547)$ & 0.35 & 0.47 & 0.61 & 0.79 & 0.81 & $0.46(1.871)$ \\
\hline High $=5$ & 0.44 & 0.59 & 0.81 & 0.77 & 0.93 & $0.49(2.296)$ & 0.37 & 0.56 & 0.68 & 0.86 & 0.81 & $0.44(2.276)$ \\
\hline \multicolumn{13}{|l|}{ MNG OWN } \\
\hline Low $=1$ & 0.80 & 0.87 & 0.99 & 1.03 & 1.16 & $0.36(1.900)$ & 0.74 & 0.84 & 0.99 & 1.02 & 1.13 & $0.39(1.950)$ \\
\hline 2 & 0.86 & 0.91 & 0.98 & 1.11 & 1.20 & $0.35(1.677)$ & 0.82 & 0.91 & 0.97 & 1.05 & 1.14 & $0.32(1.541)$ \\
\hline 3 & 0.86 & 0.94 & 1.07 & 1.09 & 1.19 & $0.33(1.793)$ & 0.76 & 0.85 & 0.89 & 1.04 & 1.12 & $0.36(1.984)$ \\
\hline 4 & 0.84 & 0.91 & 1.03 & 1.10 & 1.22 & $0.38(2.761)$ & 0.71 & 0.85 & 0.91 & 1.00 & 1.08 & $0.37(2.358)$ \\
\hline High $=5$ & 0.78 & 0.95 & 0.99 & 0.98 & 1.19 & $0.41(2.117)$ & 0.72 & 0.88 & 0.86 & 0.94 & 1.04 & $0.32(1.311)$ \\
\hline
\end{tabular}




\section{Table 6. Alphas for fund portfolios double-sorted on tail risk betas and fund characteristics}

This table contains the monthly alphas obtained by applying the Carhart (1997) model to equal- and value-weighted fund portfolios formed by independent sorts of the funds on tail risk betas and fund characteristics. The portfolios are rebalanced every 12 months. The characteristics are benchmark alpha (BNCH_ALPHA), fund size (SIZE), expense ratio (EXP_RATIO), turnover ratio (TURN_RATIO), tracking error (TR_ERROR), management fees (MNG $\overline{F E E})$, and managerial ownership (MNG OWN). The tail risk betas are estimated by running predictive regressions of the monthly returns of each fund over the previous five years (i.e., 60 monthly returns) on the aggregate tail risk. Sorting on tail risk betas, and benchmark alpha, fund size, turnover ratio, tracking error, and managerial ownership takes place monthly, and for the expense ratio and management fee the sorting is annually. For all characteristics, we sort funds in quintiles. The monthly alphas for all quintile portfolios are statistically significant at commonly used significance levels. The High-Low denotes a zero net investment portfolio that is long in quintile portfolio 5 (i.e., high tail risk beta) and short in quintile portfolio 1 (i.e., low tail risk beta). The associated $t$-statistics with Newey-West (1987) corrected standard errors for the High-Low portfolio are in parentheses, with the optimal number of lags determined following Newey and West (1994). As a proxy for the risk-free rate we use the one-month T-bill rate. As a proxy of the market return, we use the monthly return of the value-weighted portfolio of all NYSE, AMEX, and NASDAQ stocks with a share code of 10 and 11 in CRSP.

\begin{tabular}{|c|c|c|c|c|c|c|c|c|c|c|c|c|}
\hline Tail risk beta & Low $=1$ & 2 & 3 & 4 & High $=5$ & High-Low & Low $=1$ & 2 & 3 & 4 & High $=5$ & High-Low \\
\hline $\begin{array}{l}\text { By fund } \\
\text { characteristics }\end{array}$ & \multicolumn{6}{|c|}{ Equal-weighted portfolios } & \multicolumn{6}{|c|}{ Value-weighted portfolios } \\
\hline \multicolumn{13}{|c|}{$\underline{B N C H A L P H A}$} \\
\hline Low $=1$ & -0.11 & -0.05 & 0.10 & 0.06 & 0.17 & $0.28(2.178)$ & -0.19 & -0.20 & 0.07 & 0.07 & 0.17 & $0.36(2.406)$ \\
\hline 2 & -0.10 & 0.00 & 0.03 & 0.05 & 0.08 & $0.18(1.525)$ & -0.10 & 0.08 & 0.04 & 0.07 & 0.10 & $0.20(1.552)$ \\
\hline 3 & -0.03 & 0.03 & 0.05 & 0.05 & 0.11 & $0.14(1.256)$ & -0.08 & 0.04 & 0.04 & 0.07 & 0.03 & $0.11(0.912)$ \\
\hline 4 & -0.05 & 0.04 & 0.05 & 0.07 & 0.20 & $0.25(1.963)$ & -0.14 & 0.01 & -0.03 & 0.13 & 0.15 & $0.29(2.087)$ \\
\hline High $=5$ & 0.06 & 0.09 & 0.11 & 0.11 & 0.23 & $0.17(1.362)$ & 0.03 & 0.03 & 0.04 & 0.05 & 0.14 & $0.11(0.803)$ \\
\hline
\end{tabular}

\section{Continued}


Table 6. Continued

\begin{tabular}{|c|c|c|c|c|c|c|c|c|c|c|c|c|}
\hline Tail risk beta & Low $=1$ & 2 & 3 & 4 & High $=5$ & High-Low & Low $=1$ & 2 & 3 & 4 & High $=5$ & High-Low \\
\hline \multicolumn{13}{|l|}{$\underline{S I Z E}$} \\
\hline Small $=1$ & -0.04 & 0.07 & 0.11 & 0.08 & 0.26 & $0.31(2.588)$ & -0.01 & 0.06 & 0.10 & 0.05 & 0.25 & $0.26(2.200)$ \\
\hline 2 & -0.08 & -0.02 & 0.06 & 0.09 & 0.24 & $0.32(2.305)$ & -0.10 & -0.02 & 0.05 & 0.09 & 0.24 & $0.34(2.391)$ \\
\hline 3 & -0.16 & -0.03 & 0.12 & 0.16 & 0.11 & $0.27(2.383)$ & -0.16 & -0.03 & 0.11 & 0.16 & 0.11 & $0.27(2.392)$ \\
\hline 4 & -0.09 & 0.01 & 0.04 & 0.07 & 0.14 & $0.23(2.043)$ & -0.10 & 0.02 & 0.03 & 0.07 & 0.12 & $0.22(1.953)$ \\
\hline Large $=5$ & -0.11 & 0.00 & 0.06 & 0.12 & 0.17 & $0.27(2.264)$ & -0.14 & 0.02 & 0.06 & 0.11 & 0.15 & $0.28(2.260)$ \\
\hline \multicolumn{13}{|l|}{$\underline{E X P} R A T I O$} \\
\hline Low $=1$ & -0.09 & 0.01 & 0.12 & 0.13 & 0.16 & $0.25(1.891)$ & -0.07 & 0.03 & 0.11 & 0.15 & 0.23 & $0.30(2.216)$ \\
\hline 2 & -0.10 & 0.03 & 0.01 & 0.09 & 0.17 & $0.27(1.995)$ & -0.19 & 0.00 & -0.02 & 0.14 & 0.14 & $0.33(2.261)$ \\
\hline 3 & -0.07 & -0.02 & 0.05 & 0.14 & 0.20 & $0.28(2.045)$ & -0.09 & -0.10 & -0.03 & 0.19 & 0.18 & $0.27(1.761)$ \\
\hline 4 & -0.08 & 0.00 & 0.12 & 0.07 & 0.20 & $0.28(2.229)$ & -0.23 & -0.21 & 0.18 & 0.05 & 0.13 & $0.36(2.718)$ \\
\hline High $=5$ & -0.14 & 0.01 & 0.17 & 0.12 & 0.28 & $0.42(3.287)$ & -0.14 & -0.04 & 0.13 & 0.01 & 0.11 & $0.25(1.770)$ \\
\hline
\end{tabular}

\section{Continued}


Table 6. Continued

\begin{tabular}{|c|c|c|c|c|c|c|c|c|c|c|c|c|}
\hline Tail risk beta & Low $=1$ & 2 & 3 & 4 & High $=5$ & High-Low & Low $=1$ & 2 & 3 & 4 & High $=5$ & High-Low \\
\hline \multicolumn{13}{|l|}{$\underline{T U R N} R A T I O$} \\
\hline Low $=1$ & 0.00 & 0.04 & 0.10 & 0.14 & 0.19 & $0.19(1.703)$ & -0.04 & 0.04 & 0.09 & 0.13 & 0.24 & $0.28(2.588)$ \\
\hline 2 & -0.11 & 0.00 & 0.11 & 0.16 & 0.22 & $0.33(2.724)$ & -0.16 & 0.00 & 0.06 & 0.12 & 0.23 & $0.39(3.241)$ \\
\hline 3 & -0.08 & 0.04 & 0.10 & 0.13 & 0.17 & $0.25(2.040)$ & -0.12 & 0.03 & 0.06 & 0.10 & 0.13 & $0.25(1.664)$ \\
\hline 4 & -0.10 & 0.00 & 0.04 & 0.04 & 0.18 & $0.28(2.039)$ & -0.06 & -0.03 & -0.07 & 0.04 & 0.12 & $0.18(1.257)$ \\
\hline High $=5$ & -0.15 & -0.02 & 0.04 & 0.08 & 0.26 & $0.42(3.614)$ & -0.15 & -0.05 & -0.03 & 0.10 & 0.10 & $0.25(1.793)$ \\
\hline \multicolumn{13}{|l|}{$\underline{T R E R R O R}$} \\
\hline Small $=1$ & -0.05 & 0.02 & 0.02 & 0.15 & 0.19 & $0.24(1.818)$ & -0.08 & -0.02 & 0.00 & 0.14 & 0.04 & $0.12(0.686)$ \\
\hline 2 & -0.05 & 0.03 & 0.10 & 0.14 & 0.21 & $0.26(2.004)$ & -0.06 & 0.12 & 0.15 & 0.16 & 0.17 & $0.23(1.491)$ \\
\hline 3 & -0.08 & 0.07 & 0.17 & 0.26 & 0.38 & $0.46(3.264)$ & -0.10 & 0.02 & 0.23 & 0.33 & 0.41 & $0.51(3.535)$ \\
\hline 4 & 0.00 & -0.03 & 0.24 & 0.26 & 0.28 & $0.28(1.988)$ & -0.04 & -0.10 & 0.18 & 0.24 & 0.20 & $0.24(1.274)$ \\
\hline Large $=5$ & -0.20 & 0.02 & 0.18 & 0.07 & 0.24 & $0.44(2.375)$ & -0.25 & -0.01 & 0.13 & -0.04 & 0.14 & $0.39(2.322)$ \\
\hline
\end{tabular}

\section{Continued}




\section{Table 6. Continued}

\begin{tabular}{|c|c|c|c|c|c|c|c|c|c|c|c|c|}
\hline Tail risk beta & Low $=1$ & 2 & 3 & 4 & High $=5$ & High-Low & Low $=1$ & 2 & 3 & 4 & High $=5$ & High-Low \\
\hline \multicolumn{13}{|l|}{ MNG FEE } \\
\hline Low $=1$ & -0.12 & -0.02 & 0.10 & 0.10 & 0.22 & $0.34(2.745)$ & -0.17 & 0.00 & 0.08 & 0.08 & 0.17 & $0.34(2.197)$ \\
\hline 2 & -0.14 & 0.00 & 0.09 & 0.16 & 0.34 & $0.47(3.540)$ & -0.14 & -0.06 & 0.09 & 0.18 & 0.30 & $0.44(2.771)$ \\
\hline 3 & -0.14 & -0.09 & 0.05 & 0.13 & 0.27 & $0.41(2.820)$ & -0.22 & -0.06 & 0.06 & 0.10 & 0.33 & $0.55(3.526)$ \\
\hline 4 & -0.21 & -0.09 & 0.04 & 0.10 & 0.21 & 0.42 (3.139) & -0.23 & -0.11 & -0.02 & 0.15 & 0.14 & $0.37(2.190)$ \\
\hline High $=5$ & -0.22 & -0.04 & 0.15 & 0.12 & 0.19 & $0.41(2.975)$ & -0.28 & -0.06 & 0.01 & 0.21 & 0.11 & $0.38(2.576)$ \\
\hline \multicolumn{13}{|l|}{ MNG OWN } \\
\hline Low $=1$ & -0.10 & -0.02 & 0.08 & 0.05 & 0.16 & $0.26(2.109)$ & -0.17 & -0.02 & 0.10 & 0.06 & 0.13 & $0.30(2.173)$ \\
\hline 2 & -0.07 & 0.03 & 0.08 & 0.16 & 0.21 & $0.28(2.138)$ & -0.09 & 0.05 & 0.12 & 0.15 & 0.18 & $0.27(2.019)$ \\
\hline 3 & -0.04 & 0.03 & 0.13 & 0.15 & 0.19 & $0.24(1.984)$ & -0.14 & -0.03 & -0.02 & 0.11 & 0.15 & $0.29(2.416)$ \\
\hline 4 & -0.10 & -0.01 & 0.09 & 0.14 & 0.23 & $0.33(3.300)$ & -0.22 & -0.07 & -0.02 & 0.04 & 0.13 & $0.35(3.211)$ \\
\hline High $=5$ & -0.13 & 0.03 & 0.03 & 0.08 & 0.20 & $0.32(2.634)$ & -0.22 & -0.06 & -0.10 & 0.00 & 0.04 & $0.26(1.633)$ \\
\hline
\end{tabular}




\section{Table 7. Tail risk and mutual fund characteristics}

This table reports the Fama-MacBeth (1973) cross-sectional regression coefficients of mutual fund tail risk betas at time $t+1$ on a number of fund characteristics at time $t$. We divide these characteristics into two groups. The first group comprises the natural logarithm of fund size (SIZE) (in \$billions), age (AGE) (in years) and corporate governance score (CGS) (on a scale from 0 (worst) to 100 (best)). The second group comprises the management fee (MNG_FEE) (in \%), manager tenure (MNG_TEN) (in years), and managerial ownership (MNG_OWN) (in \%). We control for recent fund performance by including the fund return (RET), flow (FLOW), and volatility (VOL) estimated over the previous 12 months. To ease the interpretation of the estimated coefficients, we cross-sectionally standardize all variables to have a mean of zero and a standard deviation of one. The associated $t$-statistics with Newey-West (1987) corrected standard errors are given in parentheses, with the optimal number of lags determined following Newey and West (1994). The '*', '**', and '***' indicate statistical significance at the $10 \%, 5 \%$, and $1 \%$ levels respectively. All data come from Morningstar except for the management fee which is collected from the CRSP Mutual Fund database.

\begin{tabular}{llll}
\hline & $\mathbf{( 1 )}$ & $\mathbf{( 2 )}$ & $\mathbf{( 3 )}$ \\
\hline SIZE & $-0.086^{* * *}$ & & $-0.080^{* * *}$ \\
& $(-6.438)$ & $(-6.007)$ \\
AGE & $-0.083^{* * *}$ & & $-0.022^{* * *}$ \\
CGS & $(-4.039)$ & & $(-2.451)$ \\
& $-0.056^{* * *}$ & & -0.011 \\
MNG_FEE & $(-2.835)$ & & $(-0.475)$ \\
MNG_TEN & & $0.147^{* * *}$ & $0.138^{* * *}$ \\
& & $(7.510)$ & $(6.777)$ \\
MNG_OWN & & -0.004 & -0.002 \\
FLOW & & $(-1.098)$ & $(-0.486)$ \\
RET & & $-0.053^{* *}$ & $-0.172 * * *$ \\
& & $(-2.159)$ & $(-5.191)$ \\
\hline
\end{tabular}

\section{Continued}


Table 7. Continued

\begin{tabular}{llll}
\hline & $\mathbf{( 1 )}$ & $\mathbf{( 2 )}$ & $\mathbf{( 3 )}$ \\
\hline VOL & -0.040 & -0.089 & -0.087 \\
& $(-0.796)$ & $(-1.541)$ & $(-1.549)$ \\
Adjusted $\boldsymbol{R}^{2}$ & 0.274 & 0.271 & 0.304 \\
\hline
\end{tabular}


Figure 1. Annual average fund size and average number of funds, 1985-2015

This figure shows the average fund size (\$) and the average number of funds in our sample for each year from January 1985 to September 2015.

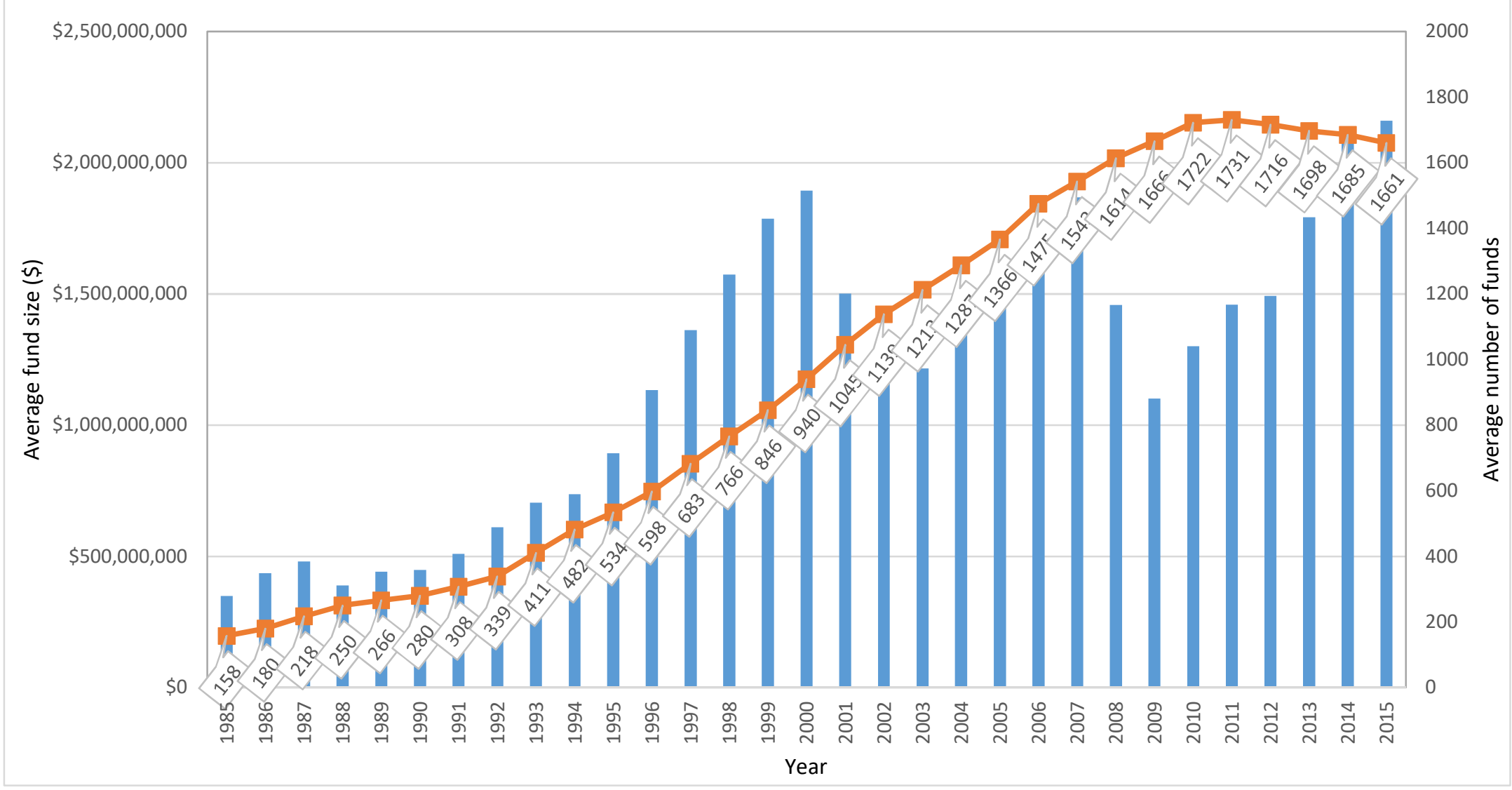




\section{Figure 2. Aggregate tail risk and three-year subsequent return of equal-weighted portfolio of mutual funds}

This figure shows the monthly aggregate tail risk and the three-year subsequent return of an equal-weighted portfolio of all funds in our sample. To facilitate comparison, both time series are standardized to have a zero mean and unit standard deviation.

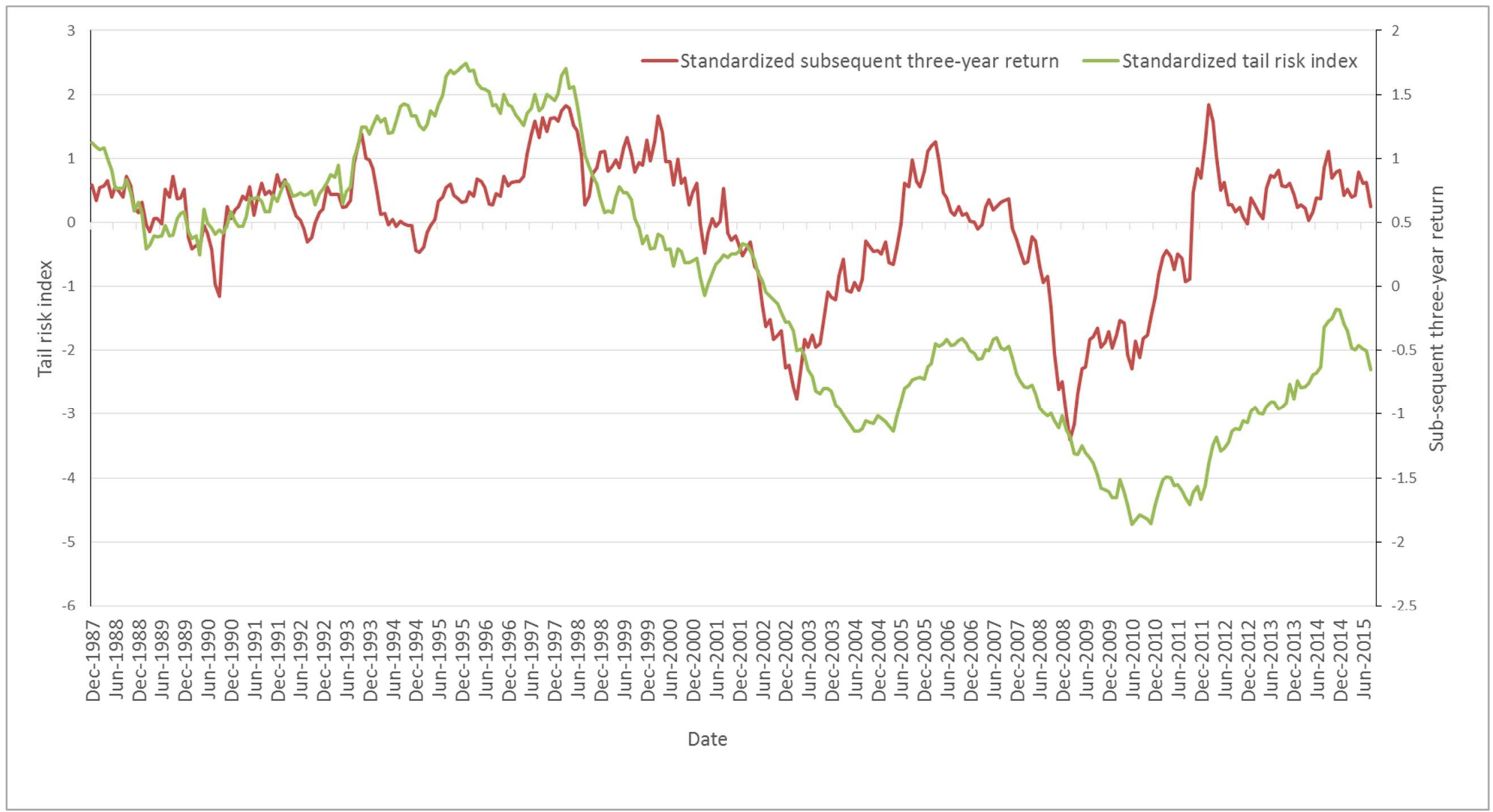


Figure 3. Alphas for equal-weighted High-Low portfolios formed on equity style

This figure shows the monthly alphas obtained by regressing the monthly returns of the equal-weighted High-Low portfolios formed on Morningstar's equity style classifications, on the CAPM that controls for market risk; on the Fama and French's three-factor model (FF) that also controls for size, and book-to-market; on Carhart's four-factor model ( $\mathrm{FF}+\mathrm{Mom}$ ) that also controls for momentum; and on Pastor and Stambaugh's five-factor model (FF+Mom+Liq) that also controls for liquidity. The portfolios are rebalanced every 12 months. The High-Low denotes a zero net investment portfolio that is long in quintile portfolio 5 (i.e., high tail risk beta) and short in quintile portfolio 1 (i.e., low tail risk beta). The tail risk betas are estimated by running predictive regressions of the monthly returns of each fund over the previous five years (i.e., 60 monthly returns) on the aggregate tail risk. As a proxy for the risk-free rate we use the one-month T-bill rate. As a proxy of the market return, we use the monthly return of the value-weighted portfolio of all NYSE, AMEX, and NASDAQ stocks with a share code of 10 and 11 in CRSP.

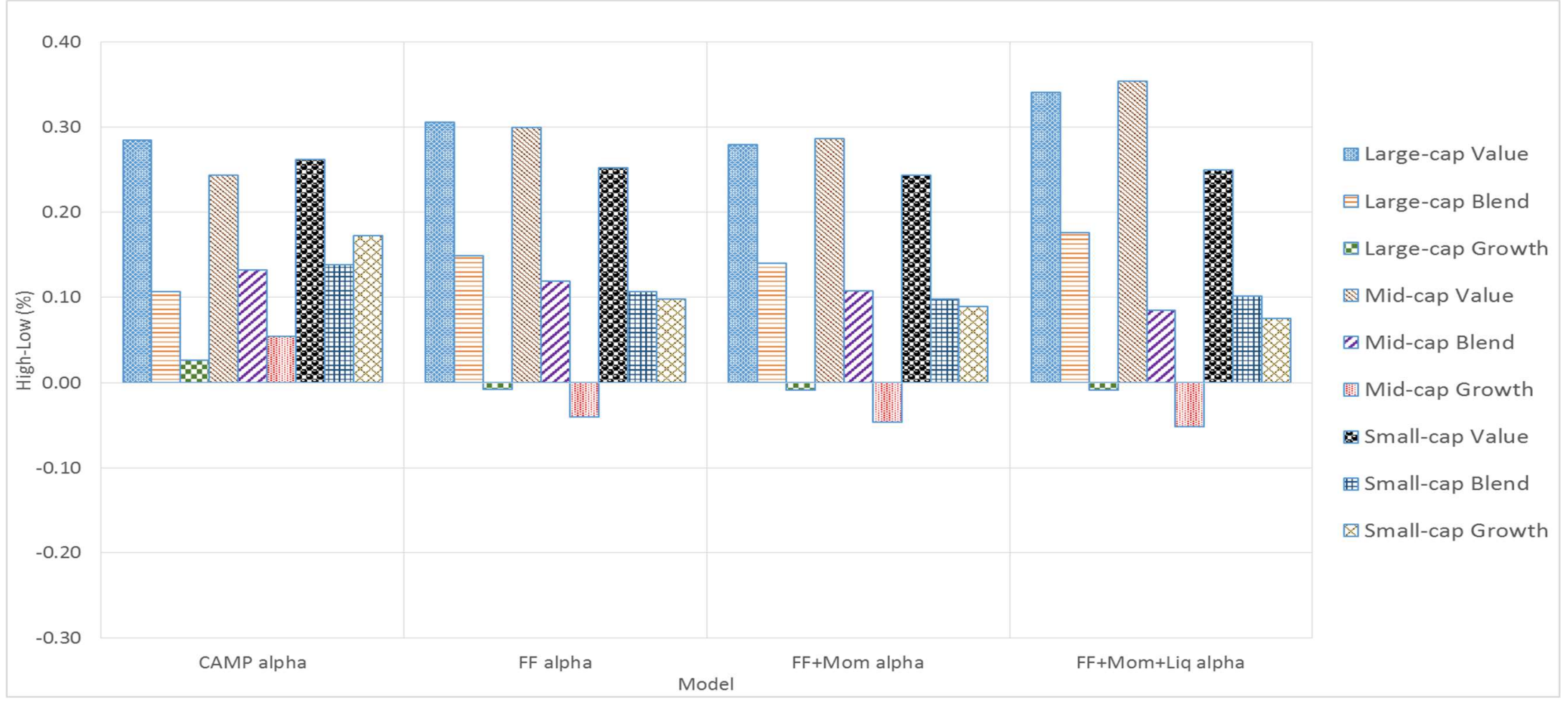


Figure 4. Alphas for value-weighted High-Low portfolios formed on equity style

This figure shows the monthly alphas obtained by regressing the monthly returns of the value-weighted fund High-Low portfolios formed on Morningstar's equity style classifications, on the CAPM that controls for market risk; on the Fama and French's three-factor model (FF) that also controls for size, and book-to-market; on Carhart's four-factor model (FF+Mom) that also controls for momentum; and on Pastor and Stambaugh's five-factor model (FF+Mom+Liq) that also controls for liquidity. The portfolios are rebalanced every 12 months. The High-Low denotes a zero net investment portfolio that is long in quintile portfolio 5 (i.e., high tail risk beta) and short in quintile portfolio 1 (i.e., low tail risk beta). The tail risk betas are estimated by running predictive regressions of the monthly returns of each fund over the previous five years (i.e., 60 monthly returns) on the aggregate tail risk. As a proxy for the risk-free rate we use the one-month T-bill rate. As a proxy of the market return, we use the monthly return of the value-weighted portfolio of all NYSE, AMEX, and NASDAQ stocks with a share code of 10 and 11 in CRSP.

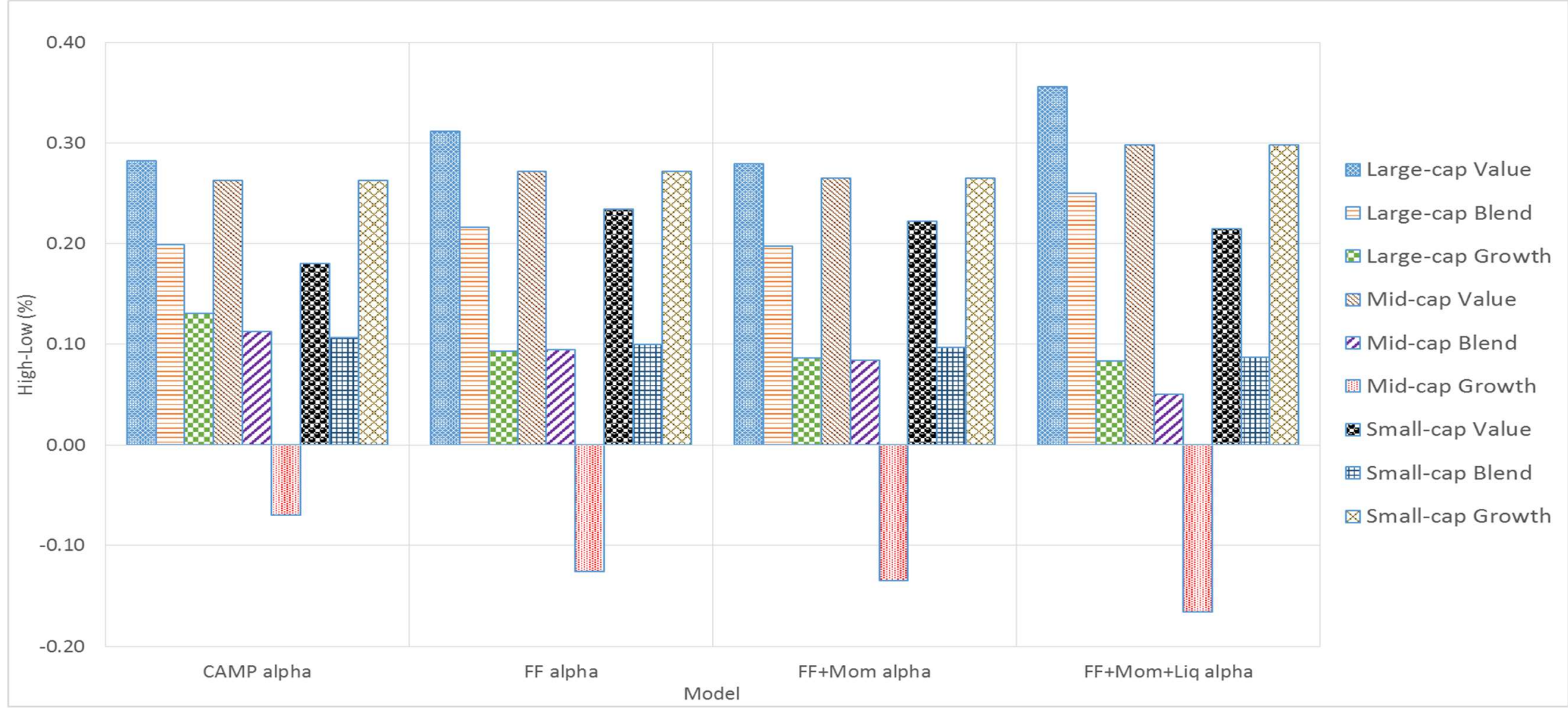

